\title{
Still a Long Way to Go:
}

\section{Implementation of the Law on Elimination of Violence against Women in Afghanistan}

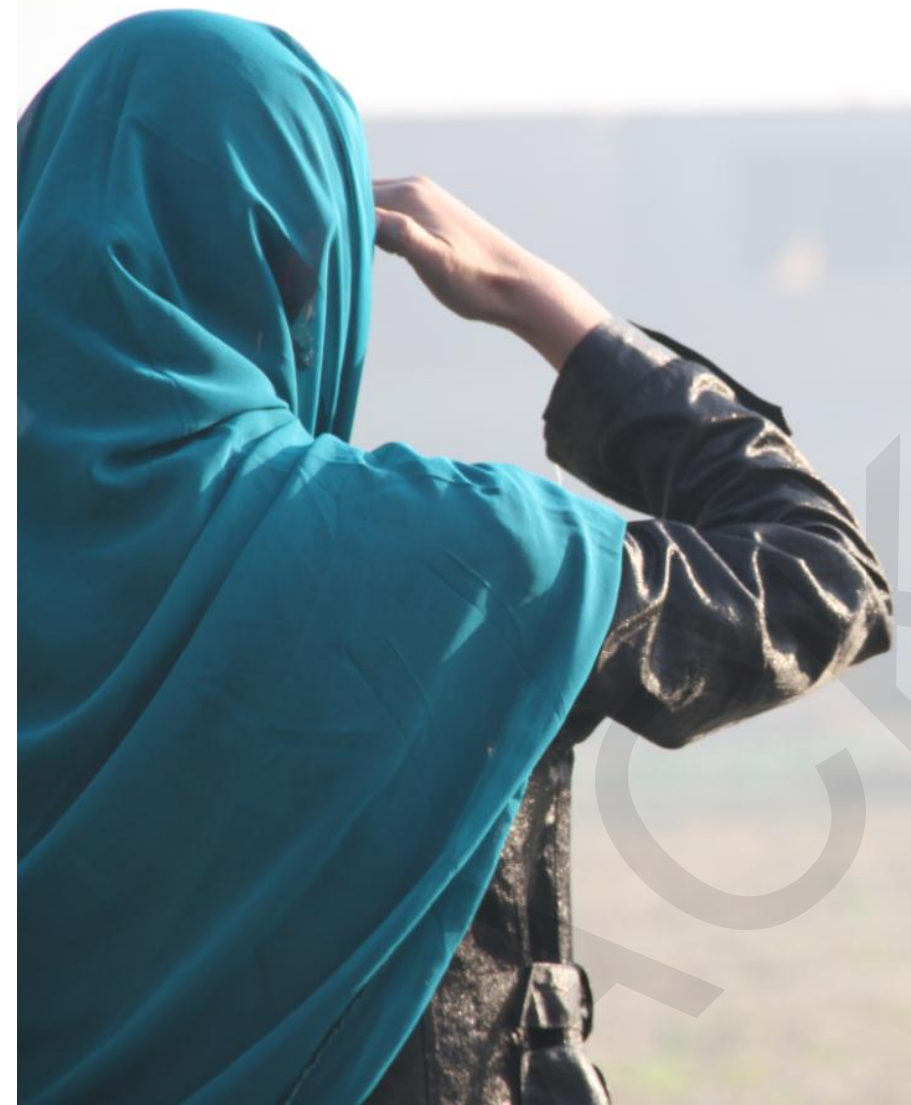




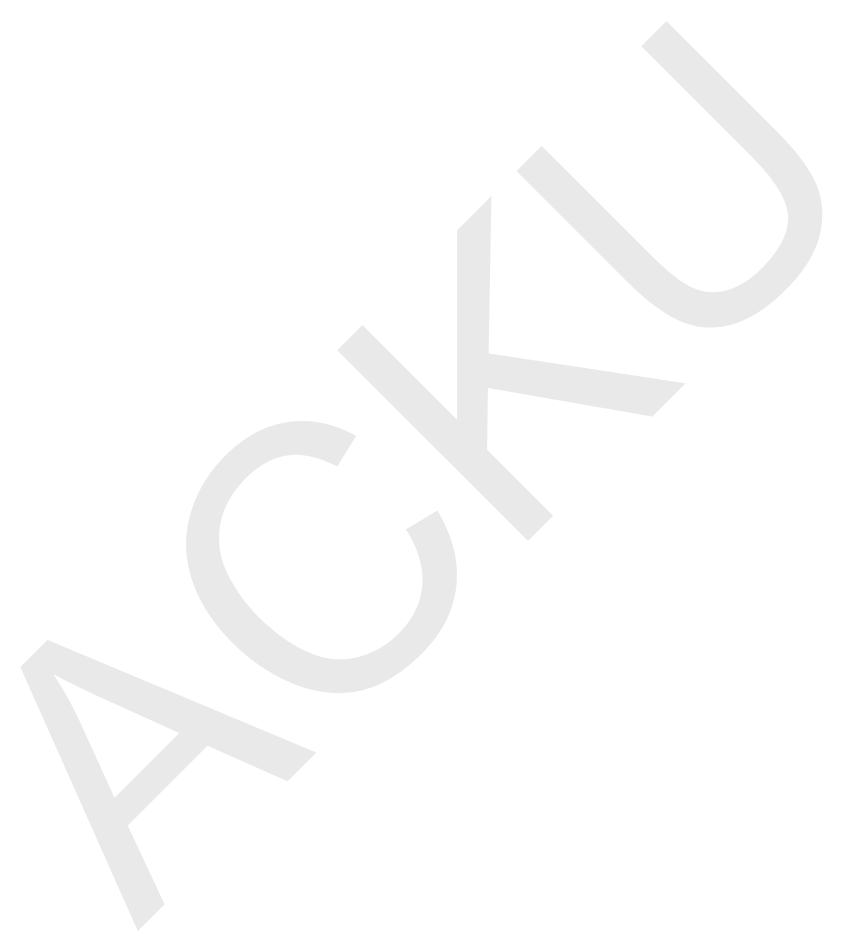




\section{Still a Long Way to Go: \\ Implementation of the Law on Elimination of Violence against Women in Afghanistan}

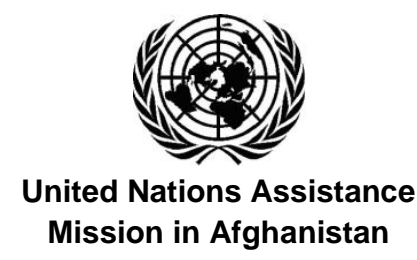

Kabul, Afghanistan

December 2012 


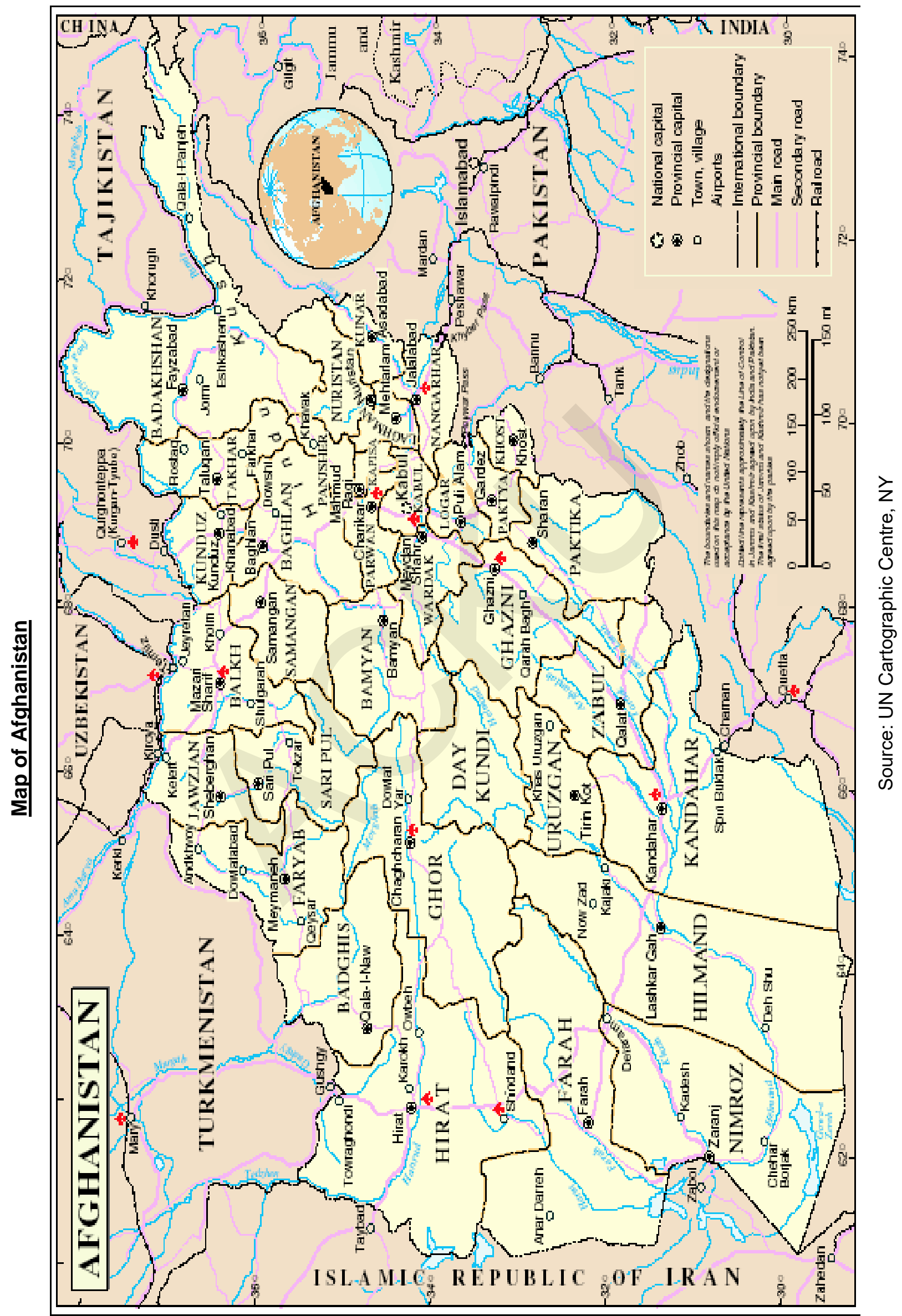




\section{Table of Contents}

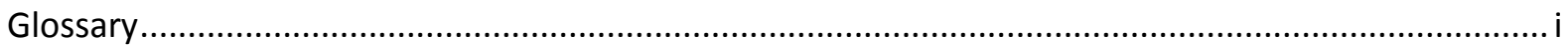

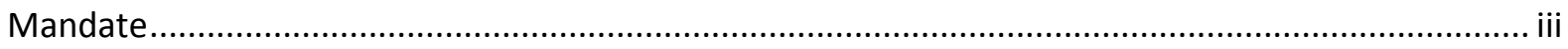

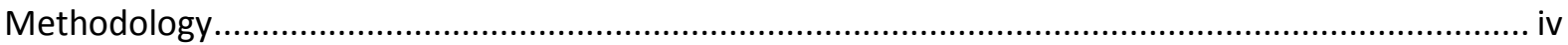

1. Executive Summary and Recommendations .............................................................. 1

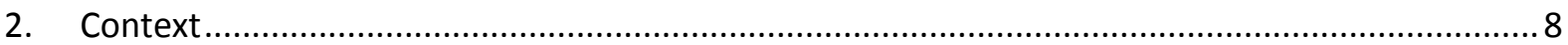

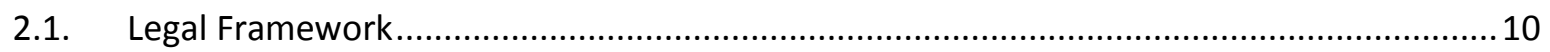

2.1.1. Law on Elimination of Violence against Women .................................................. 10

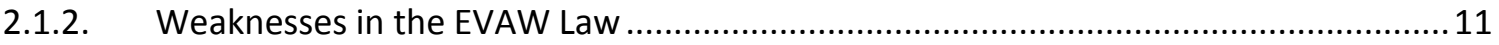

2.1.3. International legal obligations and commitments ........................................ 12

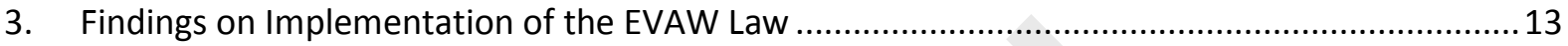

3.1. Registration of violence against women cases ................................................ 13

3.2. Application of the EVAW Law by Prosecutors and City Courts........................................16

3.3. Trends, patterns and types of violence against women incidents ................................ 19

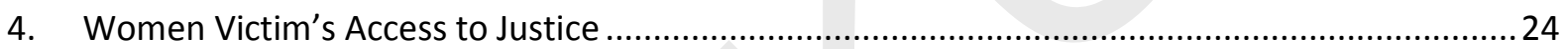

4.1. Dominance of Traditional Justice Mechanisms ...................................................... 24

4.2. Increasing control of insurgents and insecurity in some areas ......................................25

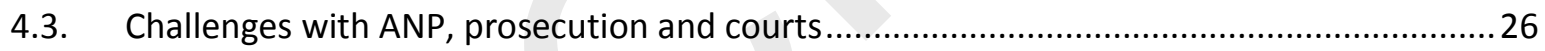

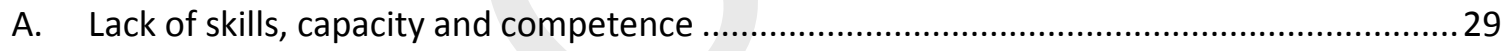

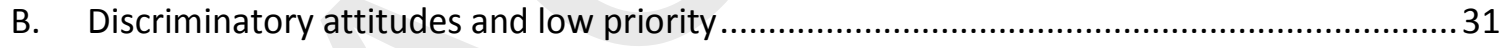

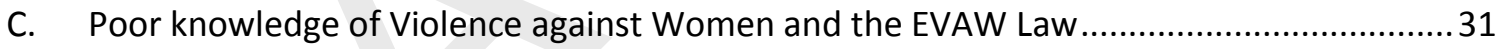

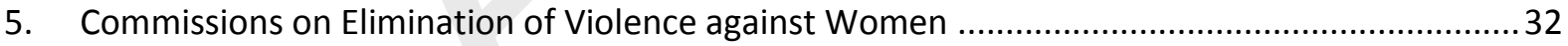

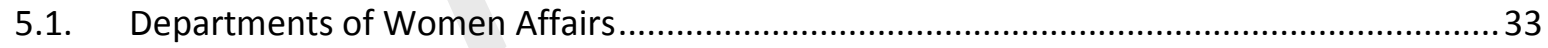

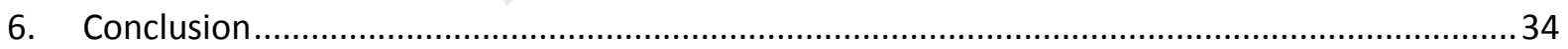

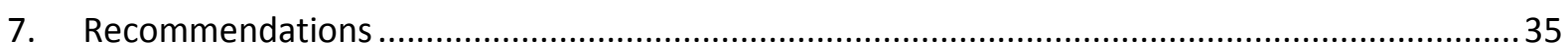




\section{Glossary}

AGO Attorney General's Office

AlHRC Afghanistan Independent Human Rights Commission

ANP Afghan National Police

ALP Afghan Local Police

CEDAW Convention on the Elimination of all Forms of Discrimination against Women

CID Criminal Investigation Division

DoWA Department of Women's Affairs

EUPOL European Police Mission in Afghanistan

EVAW law Law on the Elimination of Violence against Women

FRU Family Response Unit of the Afghan National Police

MoJ Ministry of Justice

MoWA Ministry of Women's Affairs

NAPWA National Action Plan for the Women of Afghanistan

$\mathrm{OHCHR} \quad$ Office of the United Nations High Commissioner for Human Rights

TDR Traditional Dispute Resolution Mechanisms

UNAMA United Nations Assistance Mission in Afghanistan

UN Women United Nations Entity for Gender Equality and Empowerment of Women

VaW Violence against Women

\section{Dari, Pashto and Arabic words}

Arbaki Police proposed by the local community

Ba'ad Giving a woman as restitution for murder or other crime

Jirga Gathering of elders

Mahram Husband or other close male relative with whom marriage is prohibited

Sharia Code of law derived from the Holy Koran and the teachings and example of the Prophet Mohammed

Shura Local council

Tashkil Official Government staffing table 
Ulema Religious scholars

Zina Sexual intercourse outside of marriage

Hudd Crime regarded as being against God's commands under Sharia law for which punishment is considered obligatory rather than discretionary. Seven crimes involve Hudood punishments: adultery, theft, banditry, defamation, transgression, drinking alcohol, and apostasy.

Tazeer Penalties and punishments defined by legislation rather than Sharia law 


\section{Mandate}

The United Nations Assistance Mission in Afghanistan (UNAMA) is mandated in Security Council Resolution 2041 (2012):

To monitor the situation of civilians, to coordinate efforts to ensure their protection, to promote accountability, and to assist in the full implementation of the fundamental freedoms and human rights provisions of the Afghan Constitution and international treaties to which Afghanistan is a State party, in particular those regarding the full enjoyment by women of their human rights.

UN Security Council Resolution 2041 emphasises the imperative to promote and protect the rights of Afghan women and girls and to protect them from violence and abuse as follows:

42. Recognizes that despite progress achieved on gender equality, enhanced efforts, including on measurable and action oriented objectives, are necessary to secure the rights of women and girls and to ensure all women and girls in Afghanistan are protected from violence and abuse, enjoy equal protection under the law and equal access to justice, strongly condemns discrimination and violence against women and girls.

43. Welcomes the Afghan Government's commitment to --- develop a strategy to implement fully the Elimination of Violence Against Women (EVAW) law, including services to victims, recalls that the promotion and protection of women's rights are an integral part of peace, reintegration and reconciliation.

UNAMA focuses on aspects of women's rights throughout its four priority areas of work and gives particular priority to combating violence against women and enabling their participation in the public sphere. Based on its continuous monitoring through its eight main field offices, UNAMA has issued three public reports documenting violence against women and girls including widespread harmful practices and assessing the Government's progress on providing legal protection to victims of such violations. ${ }^{1}$

In November 2011, UNAMA released a report entitled "A Long Way to Go" which presented findings on implementation of the Law on Elimination of Violence against Women by judicial and law enforcement agencies for the period March 2010 to September $2011^{2}$. The report offered 31 recommendations for improved implementation to relevant Government entities, donors and the international community.

\footnotetext{
${ }^{1}$ Silence is Violence - End Violence against Women in Afghanistan http://unama.unmissions.org/Portals/UNAMA/human\%20rights/vaw-english.pdf (July 2009).

Harmful Traditional Practices and Implementation of the Law on Elimination of Violence against Women in Afghanistan

http://unama.unmissions.org/Portals/UNAMA/Publication/Harmful\%20Traditional\%20Practices English.pdf (December 2010)

A Long Way to Go: Implementation of the Elimination of Violence against Women Law in Afghanistan http://unama.unmissions.org/Portals/UNAMA/human\%20rights/November\%2023 UNAMA-OHCHR-Joint-Reporton Implementation-of-EVAW-law ENG.pdf (November 2011).

${ }^{2}$ UNAMA jointly released A Long Way to Go: Implementation of the Elimination of Violence against Women Law in Afghanistan with the Office of the High Commissioner for Human Rights in November 2011. All references to that report as "UNAMA's report" are intended to be understood as a joint UNAMA/OHCHR report.
} 


\section{Methodology}

This report provides a synopsis of the situation of violence against women and trends in the Government's implementation of the Law on Elimination of Violence against Women (EVAW law) through reported cases of violence against women at different stages of the judicial process for the period October 2011 to September 2012. UNAMA gathered statistical and substantive information on reporting, registration, investigation and prosecution of violence against women cases and implementation of the EVAW law by prosecutors, judges and police officers from 22 provinces. From 16 of these 22 provinces, UNAMA gathered and analyzed more detailed data from police, prosecutors and courts on cases processed using the EVAW law. ${ }^{3}$

UNAMA also conducted more than 200 meetings and interviews with women victims of violence, relatives of victims and alleged perpetrators, doctors at Government hospitals, heads and representatives of provincial departments of women's affairs (DoWA), representatives of the departments of health, the Afghan National Police (ANP) and its Criminal Investigation Department (CID), the Afghanistan Independent Human Rights Commission (AIHRC), prosecutors, judges at primary courts, lawyers, representatives of legal aid organizations, national non-governmental organizations (NGOs), United Nations agencies, and journalists.

This report does not claim to provide a complete overview of the situation of violence against women in Afghanistan for the period October 2011 to September 2012. Information gained from many interviews and meetings indicates that incidents of violence against women are greatly under-reported and those incidents that reach law enforcement and judicial authorities or receive public attention through the media represent a very small percentage of the total number of such incidents. More rigorous, regular and systematic data collection is required and crucial to fully understanding the scope, nature and scale of the causes of violence against women which can better inform remedies and solutions. ${ }^{4}$

\section{Challenges in information collection}

In spite of UNAMA's continued engagement with Afghan authorities and communication on its mandate to monitor human rights violations, authorities in many areas were reticent in sharing information on violence against women. The reasons were twofold: the perception that performance of individual law enforcement actors would be judged if information was shared; and, the lack of proper registration of violence against women incidents in particular the absence of an accurate standardized dedicated case management system used by all institutions involved in responding to violence against women incidents.

As a result, UNAMA was unable to obtain a comprehensive overview of registration and follow up of violence against women incidents and implementation of the EVAW law from each concerned authority including the departments of women's affairs (DoWA), Afghan

\footnotetext{
${ }^{3}$ The 16 provinces are Badakhshan, Badghis, Bamyan, DaiKundi, Farah, Ghor, Jawzjan, Kapisa, Khost, Kunar, Laghman, Nangarhar, Paktika, Paktiya, Parwan and Samangan.

${ }^{4}$ The Afghanistan Independent Human Rights Commission (AIHRC) reported that it recorded 4,010 cases of violence against women in the first seven months of the current solar year (21 March to 21 October 2012) from across the country. AIHRC's criteria for recording or registering violence against women cases is similar but not identical to criteria used by the Afghan National Police and prosecutor's offices. AlHRC's data is available at http://www.8am.af/index.php?option=com content\&view=article\&id=28666:---28--\&catid=1:title\&ltemid=553.
} 
National Police (ANP), prosecution, and courts due to different levels of cooperation with UNAMA, differing categorization of violations as violence against women incidents by each institution, and gaps in case management and record keeping. Obtaining information directly from some of the primary courts was also not possible and in such instances UNAMA relied on secondary sources of information.

Statistics on violence against women received from institutions often included civil cases together with crimes of violence against women. Without a proper standardized case management system either within or across concerned Government departments, it was difficult to track the outcome of a given reported incident. UNAMA assessed that follow up of reported incidents of violence against women by law enforcement authorities after they had transferred cases from one institution to another was weak. This situation reflects the larger gaps in provision of a comprehensive, effective response by Government authorities to women victims of violence and in efforts to ensure their full legal protection.

UNAMA was challenged in obtaining accurate and reliable information from Afghanistan's 34 provinces and presents analysis of information gathered from 22 provinces. It was also difficult to obtain the same data sets from each Government entity across the country which made comparative analyses and use of clear criteria for evaluation and within criteria common indicators of progress very challenging.

For example, the provinces where UNAMA received information from the ANP, prosecutor's offices and courts were not identical. From Paktika and Kabul provinces UNAMA received information from the prosecution but no information from the ANP. Prosecutor's offices from Nimroz and Kandahar provinces did not share information with UNAMA while information was gathered from the ANP in these two provinces. In spite of requests, no information was obtained on violence against women cases from primary courts in Kabul and Kandahar.

Although methodology used, availability and accessibility of information and analysis undertaken by UNAMA for this report and its previous report $A$ Long Way to Go: Implementation of the Elimination of Violence against Women Law in Afghanistan were not identical making direct comparison of findings not possible, UNAMA was able to make general comparisons and observations on implementation of the EVAW law based on its findings over the two and half year period covered by the two reports. 
The list of 22 provinces where UNAMA gathered information from the ANP, prosecutor's offices and primary courts for this report is as follows:

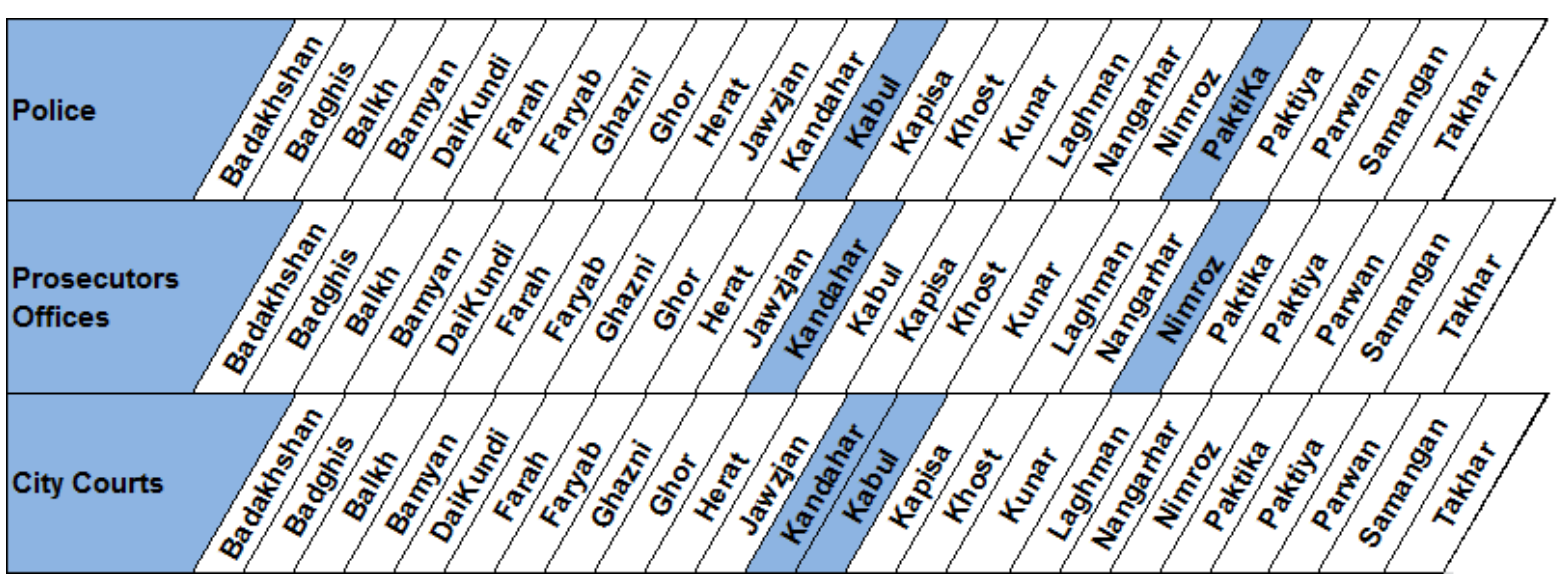

Note: No information could be obtained from the provinces highlighted. 


\section{Executive Summary}

I got married to a man in Sawa village of Anjil district five months ago. My husband and my father-in-law had beaten me without any reason several times. The repeated mistreatment had forced me to complain, but all in vain as the prosecutor overlooked my petition and warned me to either withdraw the complaint or face imprisonment.

-- Married 15-year old girl who experienced battery and laceration and who later died by forced self-immolation, Herat province, August $2012 .^{5}$

The Government of Afghanistan demonstrated its constitutional commitment to support protection of women's rights and women's equality before law through enactment of the Law on the Elimination of Violence against Women in August 2009 together with other measures. ${ }^{6}$ The landmark legislation criminalized for the first time in Afghanistan child marriage, forced marriage, forced self-immolation and 19 other acts of violence against women including rape, and specified punishments for perpetrators.

Periodic evaluation of progress on implementation of the Law on Elimination of Violence against Women, reinforced in the June 2012 Tokyo Mutual Accountability Framework, is imperative in view of the widespread occurrence of violence against women in Afghanistan and resistance to women's rights at various levels of Afghan society. Harmful practices and violence against women in Afghanistan have long prevented women from participating in public life and blocked their voices from being heard in decision-making and political forums. Progress in implementing the EVAW law can contribute to enabling women to play a meaningful and crucial role in the country's current peace and reconciliation processes. The United Nations has repeatedly stressed the imperative of ensuring equal participation of women and their full involvement in all efforts to achieve durable peace and security, and the need to increase women's role in decision-making and in conflict prevention and resolution.

This report examines implementation of the Law on Elimination of Violence against Women (EVAW law) by judicial and law enforcement officials for the period October 2011 to September 2012 and identifies the many challenges Afghan women still face in accessing justice. The analysis is based on information gathered from 22 of Afghanistan's 34 provinces and highlights the reporting, registration and judicial process followed under the EVAW law and the Penal Code by the Afghan National Police (ANP), prosecutor's offices and primary courts in a representative sample of violence against women incidents. ${ }^{7}$ From 16 provinces, UNAMA gathered and analyzed more detailed data from police, prosecutors and courts on

\footnotetext{
${ }^{5}$ Sadat, a 15-year old married girl who was victim of repeated battery and laceration that forced her to commit self-immolation on 16 February 2012. She was taken to Turkey for treatment and eventually died on 23 February 2012. UNAMA monitored her case.

${ }^{6}$ Other Government measures include establishment and regularization of the High Commission on Elimination of Violence against Women in June 2010 and creation of its provincial arms, establishment of the Special Prosecution Unit in the Attorney General's Office in March 2010, regulation on shelters in September 2011, regulation on the provision of legal aid, Presidential Decree 45 on eliminating corruption in July 2012, creation of Family Response Units in the Afghan National Police and establishment of Gender Units in various Government ministries and departments.

${ }^{7}$ UNAMA obtained information from 22 of 34 provinces due to limitations of access to certain areas of Afghanistan, lack of cooperation from law enforcement authorities, and challenges in information collection and availability. The report does not claim to provide a complete overview of the situation of violence against women in Afghanistan. See the Methodology section of this report.
} 
cases processed using the EVAW law. ${ }^{8}$ The report also highlights the crucial role and work of provincial departments of women's affairs and commissions on elimination of violence against women. This report updates earlier findings on the law's implementation in UNAMA's November 2011 report $A$ Long Way to Go: Implementation of the Elimination of Violence against Women Law in Afghanistan.

The current report found both positive progress and continuing gaps in implementation of the Law on Elimination of Violence against Women by judicial and law enforcement institutions over the 12-month period. Although prosecutors and courts were increasingly applying the law in a growing number of reported incidents of violence against women, the overall use of the law remained low indicating there is still a long way to go before women and girls in Afghanistan are fully protected from violence through the law.

Incidents of violence against women still remain largely under-reported due to cultural restraints, social norms and taboos, customary and religious beliefs, discrimination against women that leads to wider acceptance of violence against women, fear of social stigma and exclusion, and at times threat to life. Those incidents that reach law enforcement and judicial authorities or receive public attention through the media due to their egregious nature represent the tip of the ice-berg of incidents of violence against women throughout the country.

However, the number of violence against women incidents reported to certain organizations and entities ${ }^{9}$ increased over the reporting period which is an encouraging development. The Afghanistan Independent Human Rights Commission recorded 4,010 cases of violence against women from 21 March to 21 October 2012 throughout Afghanistan compared to 2,299 cases it recorded for the entire solar year in 2011 (from 21 March 2010 to 21 March 2011). ${ }^{10}$ Increased reporting may be the result of increased public awareness and sensitization to violence against women and its harmful and criminal consequences, and to women's rights generally through efforts of civil society organizations, the Government and international actors. For these reasons, increased reporting may not necessarily reflect an increase in actual incidents of violence against women.

UNAMA observed that prosecutors from 22 provinces registered 1,538 reported incidents of violence against women. ${ }^{11}$ This indicates a sharp increase in registration of reported incidents compared to UNAMA's previous findings when prosecutors registered 529 reported incidents of violence against women from the same 22 provinces. ${ }^{12}$ More than half of the

\footnotetext{
${ }^{8}$ The 16 provinces are Badakhshan, Badghis, Bamyan, DaiKundi, Farah, Ghor, Jawzjan, Kapisa, Khost, Kunar, Laghman, Nangarhar, Paktika, Paktiya, Parwan and Samangan.

9 These include provincial departments of women's affairs, the Afghanistan Independent Human Rights

Commission, legal aid organizations, hospitals and numerous women's rights and civil society organizations.

${ }^{10}$ Information received from office of the Afghanistan Independent Human Rights Commission, Kabul, 6

December 2012. See also A Long Way to Go: Implementation of the Elimination of Violence against Women law in Afghanistan http://unama.unmissions.org/Portals/UNAMA/human\%20rights/November\%2023 UNAMAOHCHR-Joint-Report-on Implementation-of-EVAW-law ENG.pdf.

${ }^{11}$ The 22 provinces are Badakhshan, Badghis, Bamyan, Balkh, DaiKundi, Farah, Faryab, Ghazni, Ghor, Herat, Jawzjan, Kandahar, Kapisa, Khost, Kunar, Laghman, Nangarhar, Nimroz, Paktiya, Parwan, Samangan, and Takhar. For this report, the term "incident" means that prosecutor's offices registered or recorded a reported alleged crime of violence against a woman. This registration does not mean the prosecutor opened an investigation into each incident registered, referred the incident to police for investigation or to traditional dispute resolution, or proceeded with an investigation. "Registration" of a reported incident by police or a prosecutor means that a file was opened but does not necessarily mean an investigation was launched or the incident was referred to another judicial entity.

${ }^{12}$ UNAMA field monitoring September 2011.
} 
reported incidents for the current period were from two provinces, Kabul (670 incidents) and Herat (333 incidents) consistent with previous findings.

City courts from 22 provinces (excluding Kabul) registered a total of 378 cases for the same period with 225 convictions. Registration of violence against women cases by these city courts was more than four times higher compared to the previous period. ${ }^{13}$

Overall reporting of incidents of violence against women to police and registration of such incidents by the police remained low. Based on the data available, UNAMA found that ANP from 22 provinces $^{14}$ (excluding Kabul) registered a total of 740 reported incidents of violence against women from October 2011 to September 2012. This number was almost the same as previous findings. ${ }^{15}$ ANP forwarded 401 of these 740 incidents (54 per cent) to prosecutor's offices with 312 withdrawn, sent to traditional dispute resolution or the legal department of the Ministry of Justice, mediated or under process.

For 16 provinces where UNAMA was able to gather detailed information from police, prosecutors and city courts on application of the EVAW law, 470 reported incidents of violence against women were registered with ANP and prosecutors. Of the 470, prosecutors filed indictments in 163 cases of which 100 indictments resulted in conviction at trial (61 per cent). ${ }^{16} 72$ of the 163 indictments filed (44 percent) in these cases relied on the EVAW law. Of those 72 indictments, 52 (72 percent) resulted in convictions at trial using the EVAW law as the basis for a finding of guilt. These findings suggest that prosecutions of cases of violence against women were more likely to result in convictions when prosecutors based their case in whole or in part on the EVAW law.

The report noted progress in the registration and application of the EVAW law by prosecutors and primary courts compared to the previous reporting period. ${ }^{17}$ Prosecutors registered more reported incidents of violence against women and city courts issued more convictions using the EVAW law. Such progress is welcome and significant. However, when placed in the general context of 4,010 reported incidents of violence against women as recorded by the Afghanistan Independent Human Rights Commission for March to October 2012, the number of cases resolved through the judicial process and convictions using the EVAW law in the 16 provinces for October 2011 to September 2012 remained very low.

UNAMA observed the crime of battery and laceration as the most prevalent of crimes recorded under the EVAW law. An increase in incidents of honour killing was also noted. The practice of wrongful prosecution of women and girls for running away from home often to escape violence continued. The ANP registered 62 "run-away" cases, prosecutors 31 cases and courts nine cases. ${ }^{18}$ 'Running away' or "home escape" is not a crime under Afghan law or in Sharia law, however, law enforcement authorities often arrest and

\footnotetext{
${ }^{13}$ UNAMA field monitoring for the previous period documented 84 cases of violence against women registered with the same city courts.

14 Bamyan, DaiKundi, Parwan, Kapisa, Nangarhar, Kunar, Laghman, Balkh, Jawzjan, Samangan, Faryab, Takhar, Badakhshan, Khost, Paktiya, Paktika, Ghazni, Nimroz, Herat, Farah, Badghis, Ghor.

${ }^{15}$ UNAMA's field monitoring for the previous period recorded 727 incidents from the same 22 provinces.

${ }^{16}$ From the total 470 reported incidents, indictments were filed in 163 with the remaining 307 incidents referred to TDR, mediated, withdrawn or were under process.

${ }^{17}$ In the previous reporting period from the same 16 provinces, prosecutors and police registered 337 cases of violence against women with 56 convictions of which 19 (34 percent) relied on the EVAW law.

${ }_{18}$ According to the Family Response Unit of the Ministry of Interior, a total of119 cases were recorded as runaway crimes during the first eight months of solar year (March - October 2012) from 33 provinces excluding Kabul. Statistics shared with UNAMA, November 2012.
} 
prosecute women and girls for this "moral crime" charging them with the qualified 'intention' to commit zina (sexual intercourse outside of marriage) or 'pre-emptive zina'. In September 2012, the Ministers of Justice and Women's Affairs and the Deputy Interior Minister publicly condemned the practice ${ }^{19}$ which was welcomed by national and international women's rights organizations. Such official statements can go a long way in protecting Afghan women and girls from violence and unlawful imprisonment but also require effective implementation and full political support.

The report also found that rather than following required legal procedures in all cases, the Afghan National Police and prosecutor's offices continued to refer numerous cases including serious crimes to jirgas and shuras for advice or resolution which often undermined implementation of the EVAW law and reinforced harmful practices. Decisions of these mechanisms were observed to often be shaped by powerful men in local areas applying different procedures and making decisions based on a mix of tradition, varying interpretations of Islamic law and local power relations sometimes contrary to law and religious principles. As a result, vulnerable segments of society, especially women and children sometimes faced further victimization. For example, a court may have sentenced a rapist to imprisonment and at the same time a community-based mechanism may have decided the rapist should marry the victim or called for a ba'ad exchange.

UNAMA also observed that the vast majority of violence against women cases referred to traditional mechanisms for mediation were solved without due oversight by the referring entity such as the provincial department of women's affairs, ANP or prosecutors. As a consequence, women often remained at risk of recurrent violence when they returned to their families following such mediation.

The report noted patterns of reluctance by police to arrest perpetrators of violence against women connected to armed groups affiliated with Anti-Government Elements, or proGovernment militias, Arbaki, Afghan Local Police (ALP), influential persons from in or outside the Government or those who could pay bribes. UNAMA observed that ANP in some areas appeared to be powerless before perpetrators while in other areas ANP seemed to favour perpetrators due to alleged corruption and lack of impartiality in administering justice. This phenomenon combined with weak accountability mechanisms in the police and discriminatory attitudes towards women resulted in widespread impunity for perpetrators of violence against women across the country.

The issue of the capacity of the police was also observed as often hindering proper investigation of violence against women cases. The lack of empowered female police staff appointed as investigation officers hampered many women's access to justice.

UNAMA found that comprehensive official statistics on the number of reported and registered incidents and cases of violence against women in Afghanistan were not available. Moreover, no standard criteria exists of a list of violations covered under the EVAW law commonly understood and shared by the various law enforcement institutions, departments of women's affairs and the Afghanistan Independent Human Rights Commission. This situation creates huge challenges in identifying and evaluating the scope, nature and scale

\footnotetext{
${ }^{19}$ Special meeting of the Parliamentary Commission on Women, Human Rights and Civil Society, Kabul, 16 September 2012.
} 
of the causes, obstacles and prevalence of violence against women which if fully known could better inform appropriate remedies and solutions.

A majority of the provincial Commissions on Elimination of Violence against Women were found to still be struggling to fulfill their mandate. They continue to need more support and better oversight from the High Commission on Elimination of Violence against Women in Kabul (body overseeing provincial commissions) to enable them to effectively fulfill their challenging mandate.

Implementing the EVAW law is a key element of the 2008-18 National Action Plan for the Women of Afghanistan (NAPWA), which calls for the revision of Afghanistan's legislative framework and judicial system to guarantee the equality and non-discrimination of women enshrined in the Constitution and international human rights conventions. More recently, the Government reaffirmed its commitments to implement gender equality and women's rights through the Tokyo Mutual Accountability Framework. The Government in coordination with international partners identified benchmarks in five main sectors to support recovery and development of a self-reliant Afghanistan in the larger development assistance framework. They stressed implementation of the NAPWA and the EVAW law as two key indicators of the Government's performance in meeting the goals of improving governance, rule of law and human rights over the next several years.

The report found that the main obstacle in the application of the EVAW law remained at the reporting - particularly to police and prosecutors - registration and investigation stages of incidents of violence against women. Although departments of women's affairs in many provinces have proved to be instrumental in providing an effective mechanism for many women victims of violence to report incidents, challenges in women's access to formal justice institutions remained numerous.

UNAMA's findings can promote understanding of factors that impede prosecution of violence against women cases, outline the extent to which women continue to face obstacles in accessing justice, and assist with measuring the effectiveness of training, awareness-raising and other programs aimed at addressing violence against women. Ultimately improvements in EVAW law implementation and reduced incidents of violence against women can lead to improved protection of Afghan women's rights, in turn strengthening their active and crucial role in society and in efforts to achieve durable peace, security and prosperity in Afghanistan.

\section{Key Recommendations}

\section{To the Government of Afghanistan}

- At the highest levels, including the President, continue to publicly emphasize that promotion and protection of women's rights is an integral part and main priority of peace and reconciliation throughout Afghanistan, and a central pillar of the country's political, economic, and security strategies. 
- In conjunction with international partners develop a monitoring framework of commitments in the Tokyo Declaration and Presidential Decree 4520 specific to gender equality, women's empowerment, and effective implementation of the EVAW law.

\section{To the Ministry of Women's Affairs and the High Commission for the Prevention of Violence against Women}

- Design and implement referral mechanisms at the district level coordinated by the representative member's office to facilitate and follow up referral of victims of violence against women to appropriate law enforcement institutions or service providers on shelter, psycho-social support, legal aid and health care pursuant to article 16 of the EVAW law.

- Ministry of Women's Affairs coordinate with the Ministry of Interior, Ministry of Justice, and Attorney General's office to develop standard classifications and categorization criteria for common usage by all law enforcement institutions and department of women's affairs for registration of all forms of violence against women cases including those not criminalized under the EVAW law such as honour killings and so-called "moral crimes" separate from civil cases relating to women.

\section{To the Supreme Court}

- Instruct the General Criminal Division and the Inspection Department to specifically monitor the courts' proper application of the EVAW law in cases of violence against women.

\section{To the Office of the Attorney General}

- Ensure that the General Penal Department (Saranwali Jazai Omomi) and other appropriate divisions of the AGO monitor how prosecution offices are applying the EVAW law.

- Continue to create and support commissions or units in provincial prosecution offices dedicated to prosecuting cases of violence against women with qualified staff and adequate resources.

- Develop a central data base for all the prosecution offices and special units on violence against women attached to prosecution offices of all the violence against women cases.

\section{To the Ministry of Interior}

- Include as part of basic police training sensitization on violence against women and the police's role in responding to the victims needs in accordance with the EVAW law.

\footnotetext{
${ }^{20}$ The July 2012 Presidential Decree addresses corruption and governance issues and gives specific instructions to all key ministries, institutions and departments to this effect. http://www.afghanistan-un.org/2012/07/the-officeof-the-president-of-islamic-republic-of-afghanistan-decree-on-the-execution-of-content-of-the-historical-speechof-june-21-2012-in-the-special-session-of-national-

assembly/?utm source=feedburner\&utm medium=feed\&utm campaign=Feed\%3A+PermanentMissionOfAfghan istanToTheUnInNewYork+\%28Permanent+Mission+of+Afghanistan+to+the+UN+in+New+York\%29bestth.
} 
- Issue instructions to the Criminal Investigation Division, including its Family Response Unit, clarifying the type of offences that must be investigated and forwarded to the prosecution and those that may be mediated by police, and ensure that all cases mediated or referred for mediation are properly registered and officially documented.

- Create an effective mechanism for proper registration and follow up of violence against women cases that are mediated to ensure protection of victims after they return to their families/communities.

- Develop a central data base of all violence against women cases with inputs from the Criminal Investigation Division, Family Response Units and other concerned police departments.

\section{To International Donors}

- Support the Government in implementing the Tokyo Declaration through channelling development assistance towards commitments made under the Tokyo Declaration on gender equality, women's empowerment and EVAW law implementation and develop a joint monitoring framework with specific indicators to measure progress in these areas.

- Increase support to the Government in implementing the 2008-18 National Action Plan for the Women of Afghanistan (NAPWA); in particular in putting in place a national strategy to implement the EVAW law, and by providing support for the National Priority Programs "Law and Justice for All" and "Capacity Development to Accelerate NAPWA Implementation". 


\section{Context}

"A woman by the name of Storay was strangled and killed by her husband because of domestic violence and giving birth to female children and not male children".

-- District Prosecutor, Khanabad, Kunduz, January $2012 .{ }^{21}$

Violence against women and girls in Afghanistan emanates from their marginal position in society and community, strict traditional codes of conduct relegating women to subordinate roles and many harmful practices.

The public execution of a woman in Parwan province on allegations of adultery by the Taliban in June 2012, and similar reports (see section 4.2) of violence against women in areas under the control of Anti-Government Elements have raised concerns among women's rights and civil society organizations that conservative elements resistant to women's rights are again gaining strength in Afghanistan. The targeted killing of the head of DoWA in Laghman on 13 July 2012 by an improvised explosive device is another stark example of this trend. ${ }^{22}$

Women's rights activists have often asserted that violence against women is systemic as it is confined not only to families and communities but perpetuated due to law enforcement authorities lacking political will in addressing victims' complaints. Whether it is the weakness of criminal justice and law enforcement or the absence of adequate security forces in many rural communities, the inability of Government authorities to investigate or prosecute crimes committed against thousands of Afghan women and girls reinforces a culture of impunity that further impedes the advancement of women's rights.

Harmful practices and violence against women have long prevented women from participating in public life and blocked their voices from being heard in decision-making forums. Progress in implementing the EVAW law can contribute to enabling women to play a meaningful part in the country's current peace and reconciliation processes.

While noting that some rights were guaranteed to women under Islam, the All Afghanistan Ulema Council Declaration of 2 March 2012, also outlined a code of conduct for women similar to the position of Islamic fundamentalists. The Declaration defined women's position in society as subordinate to men and warned against using terms and expressions that violated this principle. ${ }^{23}$ In spite of strong condemnation by Afghan civil society and women's

\footnotetext{
${ }^{21}$ UNAMA interview with district prosecutor Khanabad district, Kunduz, January 2012.

${ }^{22}$ Although the responsibility for the killing has been attributed to the Taliban, the Head of DoWA also received threats from a senator from Uruzgan following her refusal to hand over a 19-year-old woman from Uruzgan who married the man of her choice in Laghman. The senator wanted to marry the girl and had ordered the Head of DoWA to hand her back as she knew the whereabouts of the girl and her husband. After her refusal to comply with the order, the senator reportedly started threatening her and a few days later she was killed by an improvised explosive device placed under her car. One of the relatives of the Head of DoWA stated:

"She used to receive warnings from a lot of people because of her job. The Taliban, family members of the victims she assisted, and lately a Senator from Uruzgan threatened her to death. On Thursday, we were having lunch at her place when she called the Deputy Minister of Women's Affairs and asked her to instruct her on how to react to the threats she received from the senator. Some other governmental officials and the former Head of DoWA were also seeking ways to defame or target her. Then they went outside to go to Kunar, the car exploded and she was killed". UNAMA interview with a relative of the Head of DoWA, Jalalabad 16 July 2012.

23 ".... In consideration of the clarity of verses 1 and 34 of Surah an-Nisa' [of the Qur'an], men are fundamental and women are secondary; also, lineage is derived from the man. Therefore, the use of words and expressions that contradict the sacred verses must be strictly avoided."
} 
rights groups of this declaration, no official condemnation was issued by President Karzai, and the document remains posted on his official website. ${ }^{24}$ Many women informed UNAMA that such statements caused them to be extremely concerned about roll backs to the fragile gains made in securing women's rights over the last decade. They have highlighted that they fear women's rights will be bargained away in the Government's efforts to achieve broader political gains in peace negotiations with more conservative elements in Afghan society.

However, in a radio address, on 29 November 2012, President Karzai condemned domestic violence and called on religious scholars and community leaders to help preach against "this social menace" as it stood in complete negation of Islamic instructions and human rights values to which women are entitled. The President called on mass media and radio, in particular to broadcast programmmes that help communicate messages against any form of domestic violence. ${ }^{25}$

Afghan civil society organizations, women's rights NGOs and the AlHRC have continued their advocacy on combating violence against women and have been instrumental in promoting an environment conducive for victims to report cases and access justice. Bamyan province is one example where civil society has played a key role in advocating for proper investigation and prosecutions of violence against women incidents. The transfer of a prosecutor from Bamyan on the grounds of partiality, bias and corruption is an example of the impact of civil society's advocacy. ${ }^{26}$ Although Bamyan is a province which is relatively stable, facilitating a vibrant civil society, the active engagement of only one women's rights NGO operating in Kapisa contributed to improved reporting of violence against women incidents and follow-up with the judiciary in that province. ${ }^{27}$

Afghan media have also played a positive role in bringing violence against women incidents to the public interest and attracting high profile attention. Some of the women victims' stories carried by the media also received justice which otherwise may not have been delivered in their cases. For example, on 8 November 2012, a judicial panel in Kabul found four Afghan Local Police officers from Kunduz guilty of raping an 18-year old woman, and sentenced them to 16 years imprisonment. ${ }^{28}$ In July 2012, in the case of a 15-year old girl who was tortured and locked in a toilet for over five months by her in-laws, the primary court in Kabul sentenced three of the perpetrators to 10 years' imprisonment. The appeal court confirmed this decision. However, the victim's husband, the primary accused, remains at large. ${ }^{29}$

However, such positive results are few. Most cases of violence against women do not attract wide public attention which can serve to pressure authorities to provide justice. At the same time, women victims should not have to rely on publicity to get justice. Ultimately, delivery of

\footnotetext{
http://afghanistananalysis.wordpress.com/2012/03/04/english-translation-of-Ulema-councils-declaration-aboutwomen/.

24 "Following a press conference Afghan President Hamid Karzai said he was committed to the conditions announced by the Afghan Ulema Council and noted: "This is a religious perspective for our nation and all the Muslims in Afghanistan remain committed to it." 7 March 2012, Kabul. http://www.khaama.com/karzai-supportulemas-declaration-on-gender-segregation-814.

${ }^{25}$ President Karzai, radio address, 29 November 2012, posted on the official President website: http://president.gov.af/en/news/15111

${ }^{26}$ Bamyan's chief prosecutor was removed from office on 7 October 2012, UNAMA field monitoring report, October 2012.

${ }^{27}$ UNAMA monitoring, August 2012.

${ }^{28}$ http://www.nytimes.com/2012/11/08/world/asia/afghan-militia-members-found-guilty-in-rape.html.

${ }^{29}$ UNAMA field monitoring report, October 2012.
} 
justice is the legal responsibility of the Government and local authorities, and instructions from the President or Ministers should not be required to resolve every case.

\subsection{Legal Framework}

"The perpetrators of violence against women must be arrested and brought to justice because neither the Islamic teachings nor the human rights laws allow the people to perpetrate violence against other human beings, particularly against the women. The perpetrators, whoever might they be, should be arrested and be prosecuted according to the laws"

-- Hamdullah Danishi, Kunduz Deputy Provincial Governor, August 2012. ${ }^{30}$

The Constitution of the Islamic Republic of Afghanistan (2004) sets out the legal framework for protection and advancement of human rights, including women's rights, and recognizes the need to eliminate traditions that are contrary to Islam. UNAMA's December 2010 report 'Harmful Traditional Practices and Implementation of the Law on Elimination of Violence against Women in Afghanistan', based on its analysis and consultations with religious scholars, observed that many harmful practices are not only crimes under Afghan and international human rights law but also inconsistent with Sharia law.

\subsubsection{Law on Elimination of Violence against Women}

The enactment of the EVAW law in August 2009 was a significant legislative step towards ending harmful practices and other forms of violence against women in Afghanistan. Among its objectives, the law lists "fighting against customs, traditions and practices that cause violence against women contrary to the religion of Islam," and preventing and prosecuting violence against women. ${ }^{31}$

Article 5 of the law lists 22 acts, the commission of which constitutes violence against women: rape; forced prostitution; setting into flames, using chemicals or other dangerous substances; publicizing the identity of a victim in a damaging way; forcing a woman to commit self-immolation; causing injury or disability; beating; selling and buying women for the purpose of or under pretext of marriage; ba'ad (retribution of a woman to settle a dispute); forced marriage; prohibiting the choice of a husband; marriage before the legal age; abuse, humiliation or intimidation; harassment or persecution; forced isolation; forced drug addiction; denial of inheritance rights; denying the right to education, work and access to health services; forced labour; and marrying more than one wife without observing article 86 of the Civil Code. ${ }^{32}$

The law mandates punishments for persons found guilty of committing such acts and instructs both courts and prosecutors "to give the case of violence priority and act on it expeditiously." ${ }^{33}$ The EVAW law reinforces the ANP's duty to assist victims, protect individuals' rights and freedoms, and detect, combat and investigate crime, by explicitly

\footnotetext{
${ }^{30}$ Meeting of the provincial commission on elimination of violence against women, 28 August 2012, Kunduz.

${ }^{31}$ EVAW law, article 2.

${ }^{32}$ Article 86 of the Civil Code states_Polygamy can take place after the following conditions are fulfilled:

1. When there is no fear of injustice between wives; 2. When the person has financial sufficiency to sustain the wives. That is, when he can provide food, clothes, suitable house, and medical treatment;

3. When there is legal expediency, that is when the first wife is childless or when she suffers from diseases which are hard to be treated.

${ }^{33}$ Article 7 (4) of the EVAW law.
} 
obliging the police to receive and register complaints of violence against women, deal with them according to the law, and inform the Ministry of Women's Affairs (MoWA) of its actions. $^{34}$

The EVAW law also obliges the Government to take protective and supportive measures in favor of victims. It outlines specific obligations for seven Government ministries and establishes a national High Commission for the Elimination of Violence against Women which instructed governments in Afghanistan's 34 provinces to create provincial level EVAW commissions.

\subsubsection{Weaknesses in the EVAW Law}

Women's rights activists have criticized the law for failing to create a separate offence for crimes perpetrated in the name of "honour" and for not clearly defining some other crimes, including rape, and the element of coercion that is required to distinguish it from consensual zina (sexual intercourse outside of marriage). In monitoring individual cases, UNAMA encountered numerous instances of girls and women who fled their homes to avoid forced marriage or domestic violence and who were arrested, usually charged and convicted with "intent to commit zina", commonly referred to as a "moral crime". 'Running away' or "home escape" is not a crime under Afghan law. No provision in the Penal Code addresses the issue and it is not a crime under Sharia law; however, law enforcement authorities often arrest and prosecute girls for this "moral crime".

The EVAW law offers no protection for the woman or girl who runs to escape these crimes of domestic violence and forced marriage. This situation is demonstrated by the large number of women detained in Afghan prisons for so-called "moral crimes.

On 1 February 2012, President Karzai issued a decree on the occasion of the birth of the Prophet Mohammed pardoning numerous prisoners including female prisoners convicted of 'running away from home'. Another decree specifically addressing pardoning and reduction of sentences of female prisoners was issued on International Women's Day on 8 March 2012 which specifically stated, "The convicted women who ran away from their parents' house in order to marry their ideal person or if they married their ideal person shall be forgiven unconditionally". 35

However, as noted women still continue to be arrested and detained for running away and in spite of recent public statements by Afghan officials condemning the practice.

Another concern with the EVAW law is that it requires a victim or her relative to file a complaint before State institutions will take action. This means that when a victim withdraws a complaint or fails to file due to family pressure or fear of reprisal, the Government is not required to investigate or prosecute a crime of violence against women. Article 39(2) of the EVAW law allows a complainant to withdraw her case at any stage of judicial proceedings. Exceptions are made for the crimes of rape, forced self-immolation or suicide, forced prostitution, publicizing the identity of a victim, burning or using chemical substances which must be acted on by the State irrespective of the victim's failure to file or withdrawal. UNAMA

\footnotetext{
${ }^{34}$ See articles 5 and 26 of the ANP Law, article 29(2) of the Interim Criminal Procedure Code, and article 7 and 13 of the EVAW law.

${ }^{35}$ According to the Central Prisons Directorate, 83 female prisoners were released and 406 received a reduction in their sentences as an outcome of these decrees.
} 
monitoring indicates that article 39 (2) is the most frequently invoked provision of the EVAW law with withdrawals frequent even for those serious crimes excluded from withdrawal and often leaves women vulnerable to family and societal pressures.

While recognizing that revisions of the EVAW law are necessary to fully guarantee women's rights, UNAMA and women's groups take the view that the current law, if effectively implemented, can serve as a strong and immediate tool to protect and promote women's rights leading to the reduction of practices that harm millions of Afghan women and girls.

\subsubsection{International legal obligations and commitments}

The Afghan Government is obliged under its international human rights treaty obligations ${ }^{36}$ to ensure that women have the right to equality before the law and equal protection of the law. Under international law the Government must act with due diligence to prevent and respond to violence against women, whether committed by State representatives or private individuals and organizations. ${ }^{37}$

The Government reiterated, in various agreements, its commitment to protect and promote women's rights and to ensure women's meaningful participation in the political sphere and the ongoing peace process. Implementation of the EVAW law is a key element of the 200818 National Action Plan for the Women of Afghanistan (NAPWA), which calls for revision of the legislative framework and judicial system to guarantee equality and non-discrimination enshrined in the Constitution and international human rights conventions. The Government reaffirmed its commitment to implement gender quality at the 2010 Kabul Conference and through several national priority programmes, including the "Capacity Development to Accelerate NAPWA Implementation Programme", which aims at developing the capacities of relevant Government entities to mainstream NAPWA implementation in policy-making, planning, programming, budgeting, monitoring, reporting and evaluation process. ${ }^{38}$

More recently, in the Tokyo Mutual Accountability Framework, the Government in coordination with international partners identified benchmarks in five main sectors to support recovery and development for a self-reliant Afghanistan within the larger development assistance framework. They emphasized implementation of the National Action Plan for Women of Afghanistan (NAPWA) and the EVAW law as two main indicators of the Government's performance in meeting the goals of improving governance, rule of law and human rights. ${ }^{39}$

\footnotetext{
${ }^{36}$ Afghanistan is State party to the following human rights treaties: the International Convention on Civil and Political Rights, the International Convention on Economic, Social and Cultural Rights, the Convention on the Elimination of All Forms of Racial Discrimination, the Convention on the Elimination of All Forms of Discrimination against Women, the Convention against Torture and Other Cruel, Inhuman or Degrading Treatment or Punishment, and the Convention on the Rights of the Child.

${ }^{37}$ See: CEDAW Committee General Recommendation No. 19, 1992. Also see UN General Assembly Declaration on Violence against Women, 1993, A/RES/48/104, Article $4(\mathrm{C})$ that States shall "exercise due diligence to prevent, investigate and, in accordance with national legislation, punish acts of violence against women, whether those acts are perpetrated by the State or by private persons."

${ }^{38}$ National Priority Programs (NPP) are the Government's priority programs included in the framework of the Afghan National Development Strategy (ANDS) to implement commitments made at the 2010 Kabul Conference. The Joint Coordination and Monitoring Board (JCMB) endorsed the NPP on NAPWA on 19 October 2011.

${ }^{39}$ Tokyo Framework Commitment Implementation Plan, Government of Afghanistan, August 2012 to 2015.
} 


\section{Findings on Implementation of the EVAW Law}

\subsection{Registration of violence against women cases}

Overall the number of reported incidents of violence against women increased from October 2011 to September 2012. The Afghanistan Independent Human Rights Commission recorded 4,010 incidents of violence against women for seven months from 21 March to 31 October 2012 compared to 2,299 incidents it recorded for the entire solar year in 2011 (from 21 March 2010 to 21 March 2011). ${ }^{40}$ Increased reporting may be the result of increased public awareness and sensitization on violence against women and its harmful and criminal consequences by civil society organizations and the Government and on women's rights generally. For these reasons, increased reporting may not necessarily reflect an increase in actual incidents of violence against women.

UNAMA found that information on registration of reported incidents of violence against women was not available, inaccessible or inconsistently available in some areas. No information was available from Nuristan, Zabul, Helmand, and Uruzgan provinces due to limitations of access or the absence of Government institutions. In several other provinces, UNAMA had difficulty in assessing the reliability of information received from law enforcement authorities as it contradicted the reality documented on the ground. For example, in Logar and Maidan Wardak provinces, the authorities, mainly ANP and prosecutors, informed UNAMA that they had not registered a single violence against women incident between October 2011 and September 2012. The heads of DoWA from both provinces, however, confirmed their offices had registered incidents of violence against women. ${ }^{41}$

In Panjsher province all concerned authorities, including DoWA, ANP and prosecutors, in their meetings with UNAMA, maintained that none of the justice institutions registered a single violence against women incident in the province. However, UNAMA received reports from other sources that such incidents occurred and were resolved through mediation by a Jirga, without involvement of any judicial authority or DoWA.

Based on the data available, UNAMA found that ANP from 22 provinces $^{42}$ registered a total 740 violence against women incidents from October 2011 to September 2012 (excluding Kabul province). This indicates that registration of violence against women incidents by the police remained low and was consistent with the UNAMA's previous findings (727 incidents of violence against women registered by ANP from the same 22 provinces).

\footnotetext{
40 Information received from office of the Afghanistan Independent Human Rights Commission, Kabul 6 December 2012. Also see A Long Way to Go; Implementation of the Elimination of Violence against Women law in Afghanistan http://unama.unmissions.org/Portals/UNAMA/human\%20rights/November\%2023 UNAMAOHCHR-Joint-Report-on Implementation-of-EVAW-law ENG.pdf.

${ }^{41}$ DoWA in Maidan Wardak informed UNAMA that it received five violence against women incidents during the period March - September 2012 and forwarded only one case to the ANP in July 2012 of beating of a woman from Jalerz district by her husband who was an ANP officer. The case was pending investigation by the ANP. In Logar province DoWA reported it received 17 cases, including nine cases of beating and physical abuse and two cases of forced marriage that fell under the EVAW law. DoWA mediated seven cases, referred four cases to the Huquq department for mediation purposes, referred one case to the ANP that resulted in an amicable solution, and five cases were still pending with DoWA.

42 The 22 provinces are Badakhshan, Badghis, Bamyan, Balkh, DaiKundi, Farah, Faryab, Ghazni, Ghor, Herat, Jawzjan, Kandahar, Kapisa, Khost, Kunar, Laghman, Nangarhar, Nimroz, Paktiya, Parwan, Samangan, and Takhar.
} 
ANP forwarded 401 of these cases (54 per cent) to prosecution offices. 312 reported incidents (43 per cent) were either withdrawn, forwarded to Traditional Dispute Resolution (TDR) mechanisms or the legal department of the Ministry of Justice (MoJ), mediated or were under process. For the remaining 27 reported incidents (three per cent) information on action taken by the ANP was missing (see below illustration).

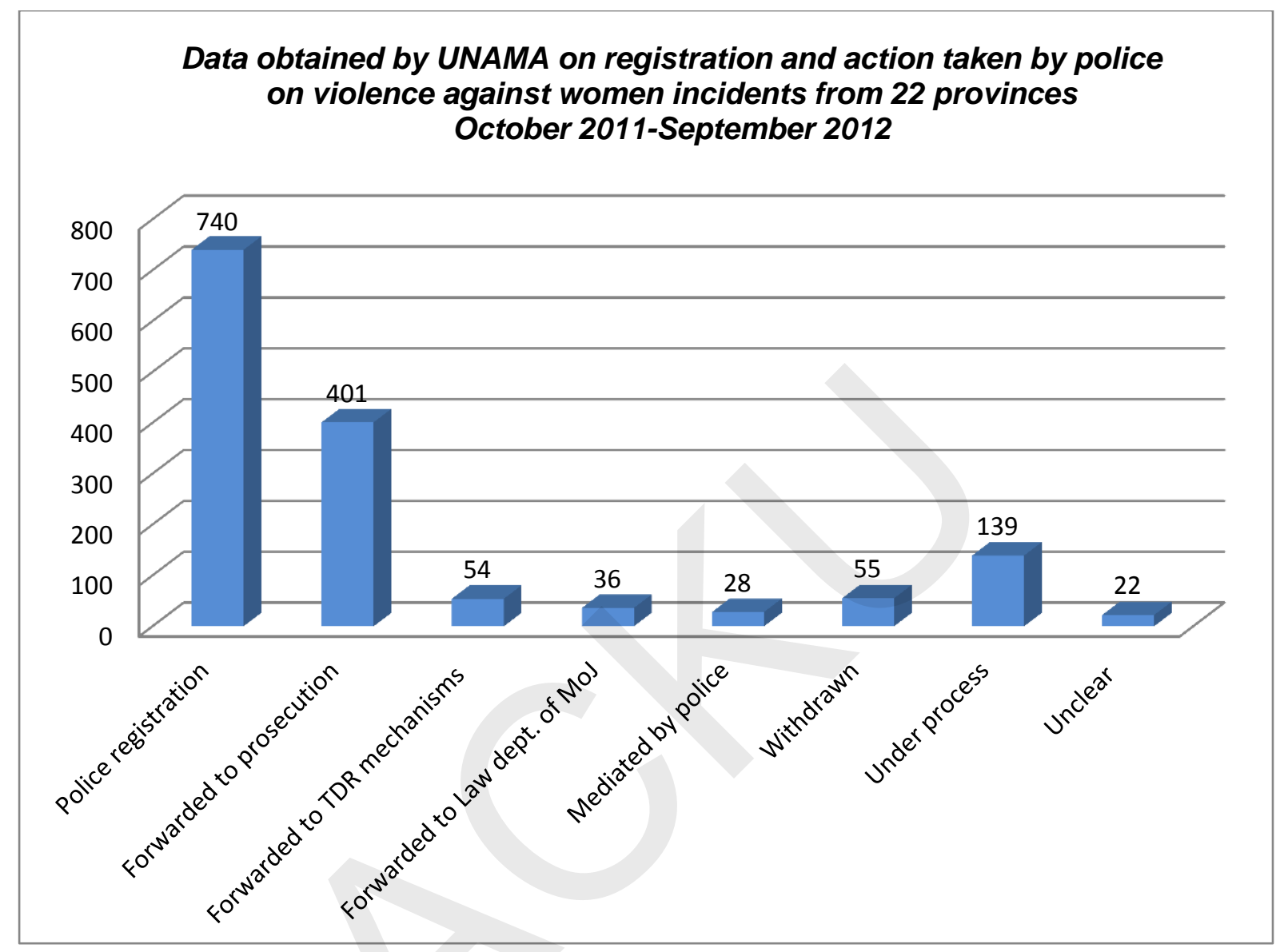

It is noteworthy that the headquarters of the Family Response Unit of the Ministry of Interior in Kabul recorded 852 violence against women incidents from provincial centers of 33 provinces (excluding Kabul) covering the period March to October 2012. The Gender and Human Rights Unit of the Ministry of Interior recorded 738 reported incidents of violence against women from all 34 provinces for March to September 2012. This is another illustration of inconsistencies in the statistics received from various offices of the same institution.

Prosecution offices from 22 provinces, ${ }^{43}$ registered 1,538 reported incidents of violence against women. This indicates a sharp increase in registration of such incidents compared to UNAMA's findings in the previous period when prosecutors registered 529 incidents of violence against women from the same 22 provinces. ${ }^{44}$ More than half of the incidents for the current period were from Kabul (670 incidents) and Herat (333 incidents) consistent with

\footnotetext{
${ }^{43}$ Badakhshan, Badghis, Bamyan, Balkh, DaiKundi, Farah, Faryab, Ghazni, Ghor, Herat, Jawzjan, Kabul, Kapisa, Khost, Kunar, Laghman, Nangarhar, Paktika, Paktiya, Parwan, Samangan, Takhar.

${ }^{44}$ UNAMA field monitoring September 2011.
} 
previous findings where 353 of the total 529 incidents were registered from Kabul and Herat provinces.

Information on further action by the prosecutor's offices for 199 of total 1,538 registered incidents was missing. Of the 1,538 incidents, 700 (46 per cent) cases were filed with the courts, 342 (22 per cent) were withdrawn, mostly through the use of article 39 of the EVAW Law. The remaining 147 (10 per cent) of cases were under process and another 146 (9.5 per cent) were forwarded to the legal department of Ministry of Justice. Only one incident was reported mediated by prosecution offices and three were reported forwarded to the TDR mechanisms from the 22 provinces. UNAMA is of the view however, that more reported incidents were either mediated or forwarded to the TDR mechanisms as monitoring indicates this is the common practice.

City courts from $22^{45}$ provinces (excluding Kabul province) registered a total of 378 cases for the same period of which 225 received convictions (59 per cent), seven were referred back to prosecutor's offices (two per cent), 43 were acquitted (11 per cent), 36 withdrawn ( 9.5 per cent), one mediated and 33 (nine per cent) were reported to be under process. UNAMA could not obtain information on the remaining 33 cases (nine percent).

Registration of cases by city courts for the current reporting period almost doubled compared to the previous period when the city courts from the same 22 provinces registered only 84 violence against women cases (see below graph).

${ }^{45}$ Bamyan, Badakhshan, Badghis, Balkh, DaiKundi, Farah, Faryab, Ghazni, Ghor, Herat, Jawzjan, Kapisa, Khost, Kunar, Laghman, Nangarhar, Nimroz, Paktika, Paktiya, Parwan, Samangan, and Takhar. 


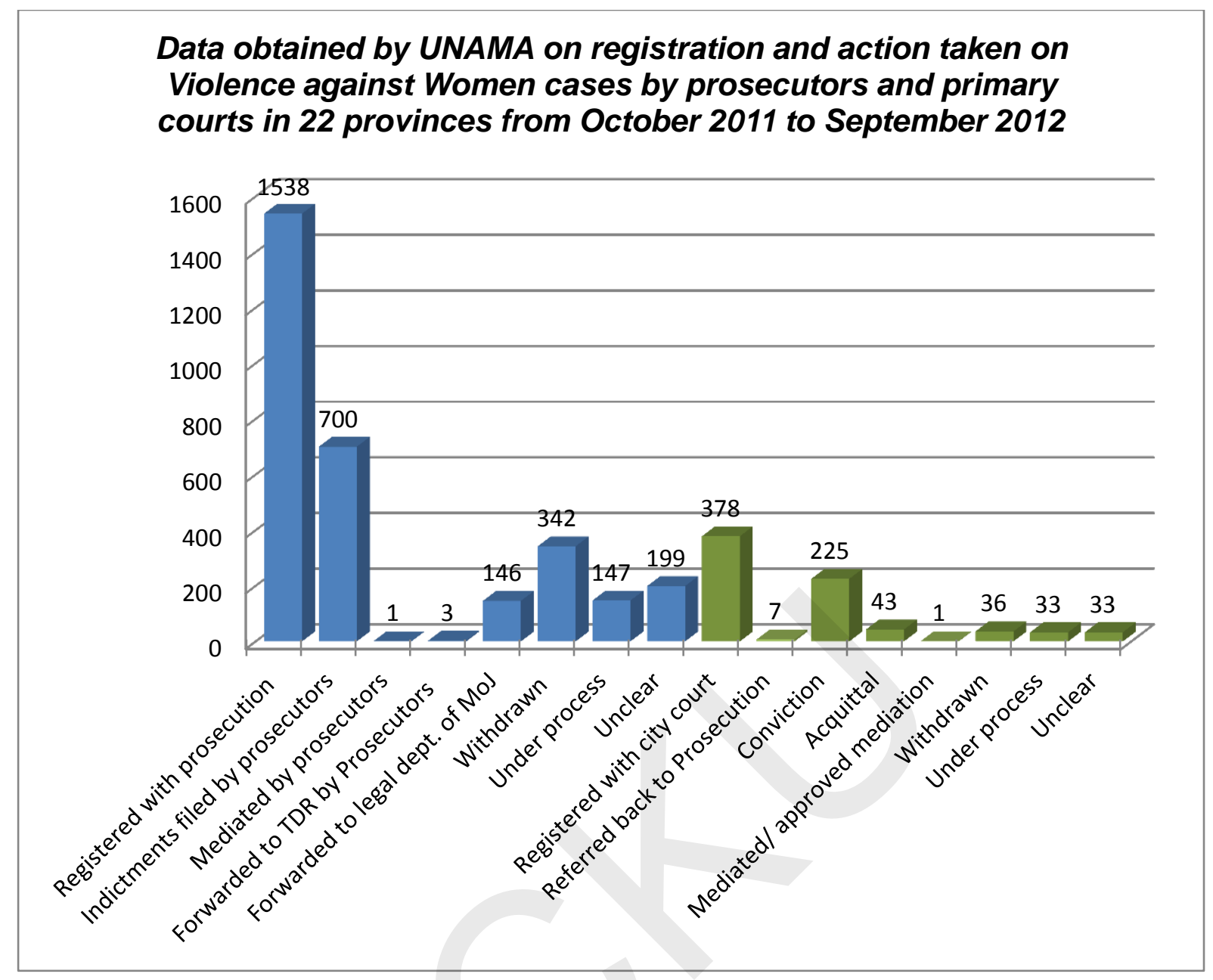

UNAMA observed that overall reporting, registration and investigation of violence against women cases compared to the number of incidents reported by the Afghanistan Independent Human Rights Commission for the period remained low, in particular with the ANP. This suggests that in spite of improved implementation by prosecutor's offices, many challenges remained in the reporting and registration of cases with law enforcement institutions (detailed further in section 4 of this report).

\subsection{Application of the EVAW Law by Prosecutors and City Courts}

In 16 provinces, UNAMA was able to obtain detailed statistics from prosecutor's offices and primary courts to inform a more detailed overview of EVAW law application by these justice institutions. $^{46}$

UNAMA findings suggest progress in application of the EVAW law by prosecutors and primary courts compared to the previous period. ${ }^{47}$

\footnotetext{
${ }^{46}$ Badakhshan, Badghis, Bamyan, DaiKundi, Farah, Ghor, Jawzjan, Kapisa, Khost, Kunar, Laghman, Nangarhar, Paktika, Paktiya, Parwan and Samangan.

47 See UNAMA report 'A Long Way to Go: Implementation of the Elimination of Violence against Women Law in Afghanistan', November 2011. Although methodology, available information and analysis used for UNAMA's two reports were not identical ruling out direct comparison, UNAMA was able to make general comparisons and observations on implementation of the EVAW law based on its findings over the two and half year period.
} 
For 16 provinces where UNAMA was able to gather detailed information from police, prosecutors and city courts on application of the EVAW law, 470 reported incidents of violence against women were registered with ANP and prosecutors. Of the 470, prosecutors filed indictments in 163 cases of which 100 indictments resulted in conviction at trial 61 per cent). 72 of the 163 indictments filed (44 percent) in these cases relied on the EVAW law. Of those 72 indictments, 52 (72 percent) resulted in convictions at trial using the EVAW law as the basis for a finding of guilt.

These findings suggest progress in the registration and application of the EVAW law by prosecutors and primary courts compared to the previous reporting period. ${ }^{48}$ More reported incidents were registered by prosecutors that resulted in more convictions using the EVAW law. However, in the general context of 4,010 reported incidents of violence against women as recorded by the AIHRC from March to October 2012, the findings suggest that only a very small percentage of incidents were processed through registration, investigation, prosecution and trial to conviction.

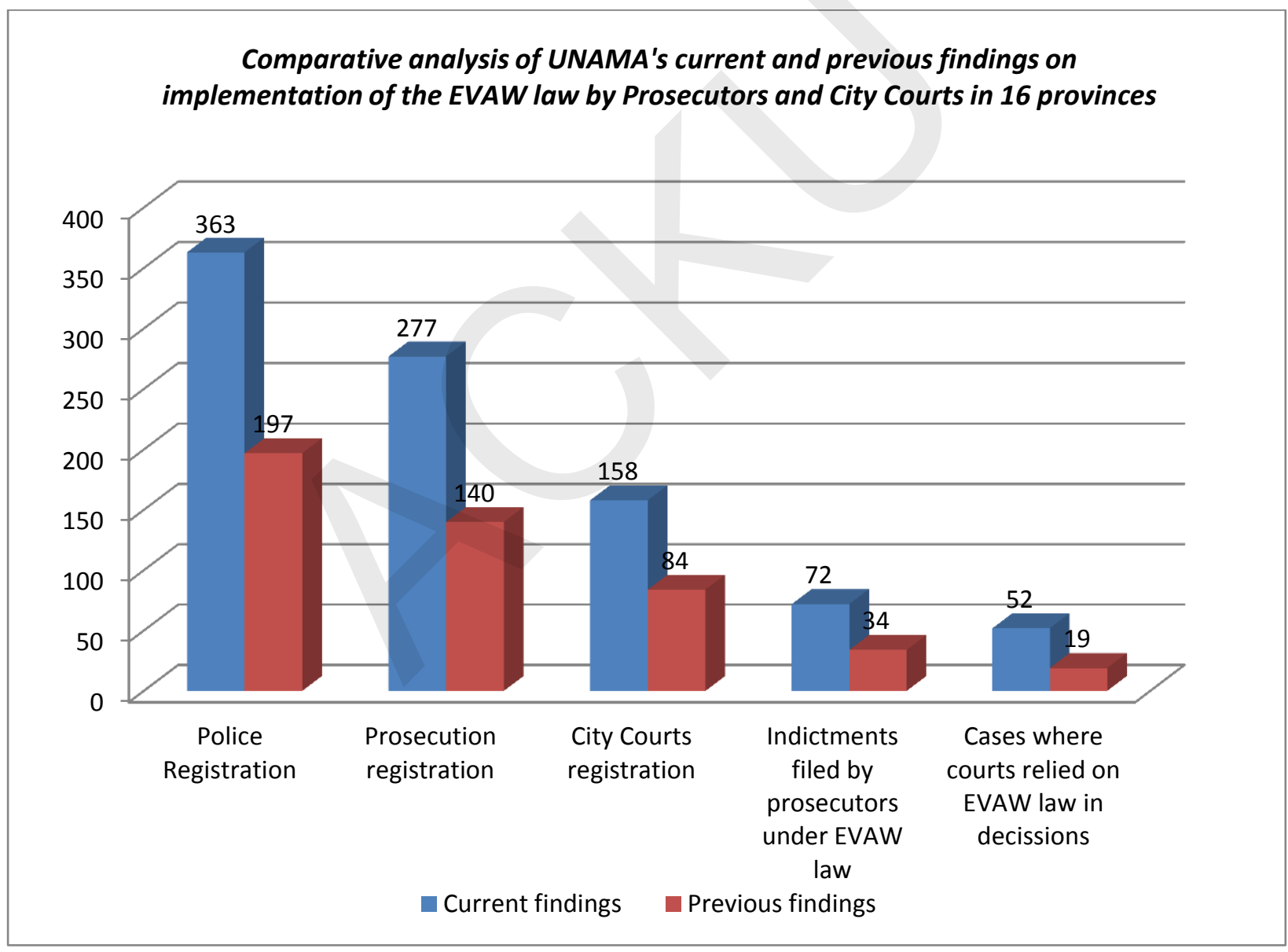

Note: To avoid duplication, 170 incidents forwarded to prosecutors by police were deducted from the total number of incidents registered by police and prosecutors between October 2011- September 2012.

\section{Other illustrative examples}

\footnotetext{
${ }^{48}$ In the previous reporting period from the same 16 provinces, prosecutors and police registered 337 cases of violence against women with 56 convictions of which 19 (34 percent) relied on the EVAW law.
} 
Herat province is not included in the list of the 16 provinces UNAMA used in its sample on detailed EVAW law implementation. The province was exceptional as the prosecution reported prosecuting 144 out of 335 registered cases (43 per cent), all under the EVAW law. Information received from Faryab province also indicated a high number of prosecutions under the EVAW law: 27 of the total 32 cases registered.

This trend, however, was not seen in other provinces. Bamyan is one example where 53 violence against women incidents were registered and dealt with by the prosecutor's office, of which 44 were defined as violations under the EVAW law, including beating ("causing injury or disability" and "battery and laceration"), ba'ad, attempted ba'ad, rape and gang rape, forced self-immolation, and intimidation and verbal abuse. However, only six cases were prosecuted $^{49}$ and tried in the primary court under the EVAW law.

In Nangarhar province, of a total of 267 cases reported to law enforcement authorities, only four were decided under the EVAW law. The referral of cases to informal justice mechanisms, the withdrawal of complaints by victims in accordance with article 39 of the EVAW law, and the ANP's inability or unwillingness to arrest alleged perpetrators, were among the main causes identified by UNAMA for poor implementation of the law.

\section{Application of the Penal Code}

The findings also suggest that application of the EVAW law does not mean the courts always took decisions in favour of women victims. ${ }^{50}$ In some cases, however the Penal Code appears to have been invoked for the benefit of victims, in particular in instances of rape, which is more explicitly defined in the Penal Code than in the EVAW law. Also, for the crime of 'beating', (stipulated under the EVAW law either under article 22 causing injury or disability or article 23 battery and laceration ${ }^{51}$ ), the Penal Code is more elaborate, particularly when it results in injury.

In some other cases, the use of the Penal Code disadvantaged victims. Many perpetrators of acts of violence against women criminalized under the EVAW law when indicted under the Penal Code were either acquitted, charged with less serious crimes, received lighter sentences, and/or victims were accused of "moral crimes". ${ }^{52}$

\footnotetext{
49 UNAMA is of the view that the number may be higher but due to challenges in cooperation as well as inaccurate record keeping accurate information was difficult to obtain.

${ }_{50}$ In a gang rape case from Bamyan that involved a tenth grade girl from Yakawlang district, the alleged two rapists (treated as juveniles by prosecutors) and a female accomplice were arrested and indicted under the EVAW law with rape and accessory to rape respectively. The primary court acquitted the three on 18 September 2012. Concerns were raised that bribery may have influenced the court's majority decision as one of the judges found the suspects guilty in a minority opinion. On 30 September, UNAMA received a petition from the victim's father stating: "These individuals committed rape and in response to this anti-Sharia and illegal act, they are free with the cooperation of Primary Court. We want Sharia law and Afghan law to be implemented and if not, we will leave the area". UNAMA"s field monitoring September 2012.

${ }^{51}$ EVAW law; Causing injury or disability, Article 22.1. If a person beats a woman considering the mitigating and aggravating circumstances, the offender in view of the circumstances shall be sentenced in accordance with Article $407-410$ of the Penal Code. 2. If the acts included in paragraph (1) of this Article results in the death of the victim, the offender in view of circumstances shall be sentenced in accordance with Article $395-399$ of the Penal Code. Battery; Article 23: If a person beats a woman which does not result in injury or disability, the offender in view of the circumstances shall be sentenced to short term imprisonment not more than three months. 52 UNAMA monitoring of individual cases of violence against women across Afghanistan from March 2010 to September 2011.
} 
UNAMA also received reports of prosecutors preferring to indict perpetrators of violence against women under the Penal Code rather than the EVAW law to allow them the benefit of a Presidential pardon. This occurred despite the fact that the Supreme Court, in July 2011 annulled article 42 of the EVAW law ${ }^{53}$, which barred pardons and mitigation of sentences of persons convicted under the law, finding it in conflict with the President's Constitutional prerogative of pardon. ${ }^{54}$ This lack of knowledge or information on the part of judicial officials is another example of the gap in communication on key legal review and policy measures from Kabul to operational judicial offices in districts.

UNAMA is of the view that wide use of the Penal Code and under-use of the EVAW law may hamper the effective implementation of the latter. Harmonization of the two laws aimed at maximizing protection for women should be considered. As suggested in UNAMA's previous reports, more training of prosecutors at the district level up, and continued monitoring by the Attorney General's Office, can also help increase use of the EVAW law, particularly for prosecution of serious crimes of violence against women (Also see section $4.3-\mathrm{C}$ of this report).

\subsection{Trends, patterns and types of violence against women incidents}

Through its field based monitoring from October 2011 to September 2012, and further to documentation from the AIHRC, UNAMA observed that violence against women remained widespread in Afghanistan. Prevalent forms of violence against women included battery and laceration, sexual violence and harmful practices, such as early and forced marriages, often leading to self-immolation, ba'ad (use of girls in marriage to settle disputes), the "crime" of running away from home and so-called "honour" killing, which is not covered under the EVAW law.

\section{Battery and laceration}

My husband removed my hair, I was beaten by rope, I was put in a room and I received only a small piece of bread in order to survive. xxx from xxxx district Badakhsan province found by a medical mobile team in a locked house and transferred to Faizabad for investigation and treatment. October $2012 .{ }^{55}$

Among the violations criminalized under the EVAW law, UNAMA found that battery and laceration was the highest among cases reported to ANP and prosecutors, with 896 complaints registered wit prosecutors (including statistics from Special Violence against Women Unit of the Attorney General's office, Kabul).

\footnotetext{
${ }^{53}$ Article 42 on suspending, pardoning and mitigation of punishment: "The punishment of crimes by offenders of violence shall not be postponed, pardoned or mitigated."

${ }^{54}$ Supreme Court Approval 27 July 2011. "[..] With regard to a query about article 42 of the EVAW law that creates problems for the implementation of presidential decrees pardoning and reducing penalties, the High Council of the Supreme Court clarifies that pardoning and reducing the penalties of prisoners is one of the constitutional competencies of the President, who can implement this in any way. Hence this article of the EVAW law contradicts Afghanistan's Constitution. As a law cannot exceed the Constitution, therefore, it is annulled and inapplicable."

${ }^{55}$ UNAMA interview with the victim in Faizabad hospital, Badakhsan province - 14 October 2012.
} 


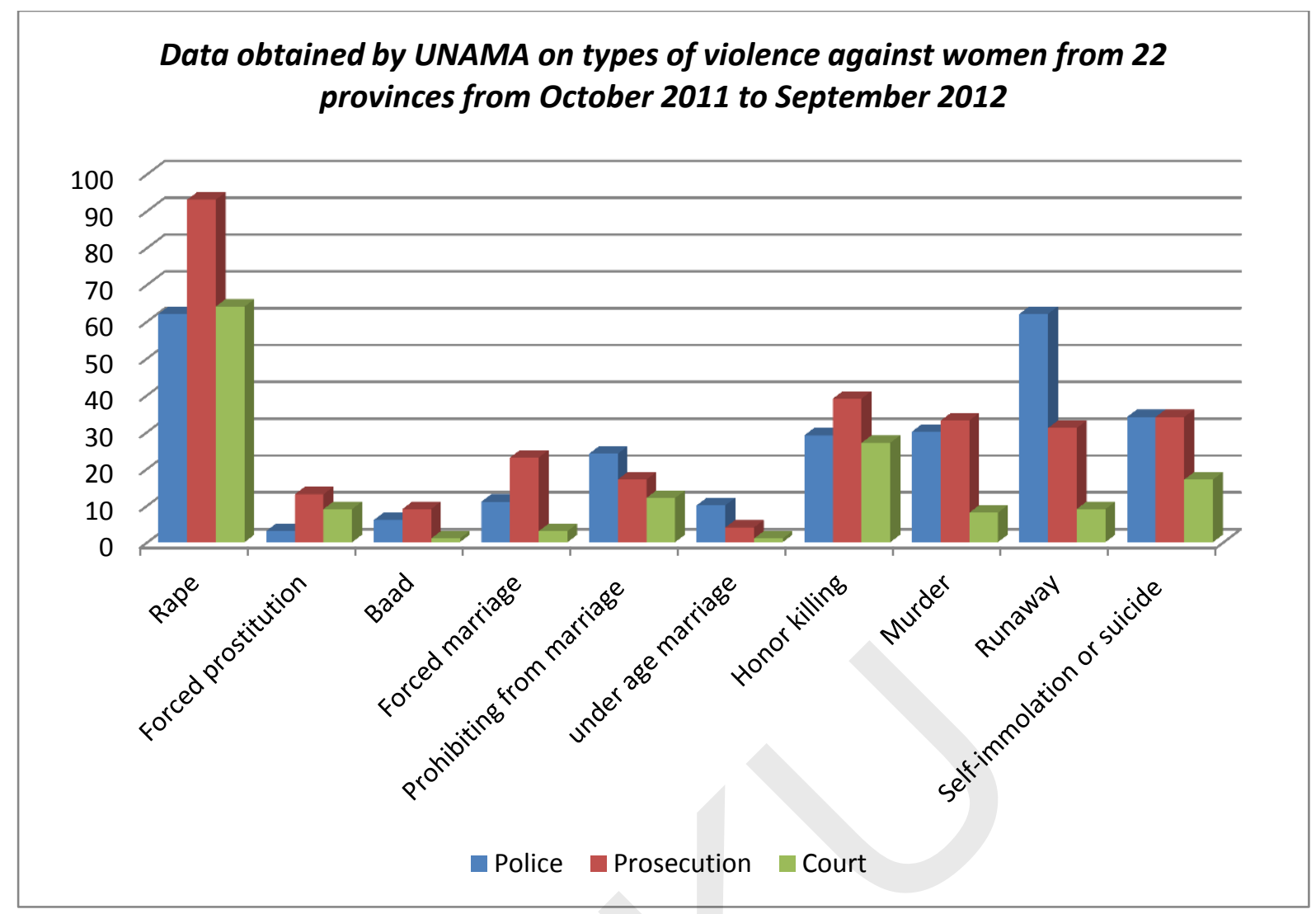

\section{Honour Killing}

Police failed to arrest the alleged perpetrator $x x x x$ who shot and killed his wife on 29 April 2012, in Baghlan-e-Jadid District, after he was told that his daughter eloped with her fiancé by the cooperation of his wife. Police say that the perpetrator is at large, while I saw him the other day near the DG office.

-- A prosecutor from, Baghlan province, September $2012 .{ }^{56}$

The Afghanistan Independent Human Rights Commission recorded 60 reported incidents of honour killings across the country, between March and August 2012, representing a sharp increase in reporting and, possibly, in the occurrence of such incidents - in comparison to 20 incidents reported for the same period in $2011 .^{57}$ Information UNAMA received from law enforcement agencies for September 2011 to October 21012 indicated registration of 29 incidents of honour killing with the ANP (15 from Faryab alone), 39 with prosecution offices (12 from Paktiya and 15 from Herat), and 27 with the courts.

\section{Sexual violence}

I was raped by three gunmen including $x x x$ brother of commander $x x x$ on 24 November when I was taken to an unknown location and forced by perpetrators to sit inside a taxi and they \{the perpetrators\} took my nude pictures and then the taxi driver was forced to stay beside me and they took my picture with the taxi driver too.

\footnotetext{
${ }^{56}$ UNAMA telephone conversation with a prosecutor, Baghlan province, 5 September 2012.

57 UNAMA meetings with Commissioner on Women's Rights, Protection, and Development, AlHRC September 2012, Kabul.
} 
Afterwards, I was left in the spot with the taxi driver and I came back to my village with him. I want the perpetrators to be trialed soon, otherwise I will commit suicide.

-- Victim of gang rape from xxx district, Baghlan province, November $2011 .^{58}$

Incidents of sexual violence including rape and forced prostitution were also high. Some of these cases received national and international media attention, and perpetrators were prosecuted. The Lal Bibi case from Kunduz province represented one such prosecution of abduction and rape. UNAMA observed that the majority of such cases however were either not investigated or the investigation and prosecution were dropped for different reasons outlined earlier in this report.

The ANP and prosecutor's offices from 22 provinces registered 63 and 93 cases of rape respectively, while courts from 22 provinces filed 64 rape cases for the reporting period. A number of rape cases were turned into adultery, particularly at the court level, mainly due to lack of clarity on required proof, traditional beliefs, over-ruling correct application of the law, as well as the influence and power of perpetrators or their allies. ${ }^{59}$

\section{"Moral crimes"}

I love $x x x$, but my family engaged me to another man from my village. Xxx and I decided to run away from [our] district to [another] province. The police arrested us in [this] province on 6 June 2012 and the prosecutor sent me for a medical examination to the public health [doctor]. I requested the doctor not to examine me as I was innocent and had not committed any action. But the doctor rejected my request and checked me and found out that my statement was correct and that there was no sign of sexual intercourse.

17-year old girl from Badakhshan province who was later released by a primary court, August $2012^{60}$

The unlawful practice of arresting and prosecuting women and girls who run away from their homes to escape domestic violence or harmful practices continued. The ANP registered 62 "run-away" cases, prosecutors 31 and courts nine.

Notably, on 11 April 2012 the Attorney Generals' Office issued an internal directive to the Special Violence against Women Unit in Kabul requesting it to instruct all prosecutors as follows:

A circulation must be prepared and shared with all relevant prosecution offices in the center and provinces and the prosecutors should be instructed not to prepare unjustifiable case files regarding running away cases that haven't been criminalized under Afghanistan laws and can't be heard by courts and refrain from conducting baseless investigations. Other circumstances where people run away to commit any other crime aren't covered by this instruction.

\footnotetext{
${ }^{58}$ UNAMA interview with victim, Baghlan, 28 November 2011.

59 UNAMA field monitoring, October 2011 - September 2012.

${ }^{60}$ UNAMA interview with the victim, Badakhshan province, 9 June 2012. The victim was reported to be released by the primary court on July 2012. UNAMA field monitoring, September 2012.
} 
The issue is being communicated to you so that you can take action in accordance with instruction of the High Council of Attorney General Office of the Islamic Republic of Afghanistan. ${ }^{, 61}$

It is unclear whether and to what extent the Special Violence against Women Unit of the Attorney General's Office implemented this directive or whether they monitor compliance. According to some sources ${ }^{62}$, prosecutor's offices in Kabul, Nangarhar, Balkh, Herat ${ }^{63}$ and Parwan received the document but with no further instruction included.

'Running away' or "home escape" is not a crime under Afghan law. No provision in the Penal Code addresses the issue nor is it a crime under Sharia law; however, law enforcement authorities often arrest and prosecute girls for this "crime".

In the formal judicial system, women and girls who run away are sometimes charged with the qualified 'intention' to commit zina or 'pre-emptive zina' [zina, adultery, is a Huduud crime under Islamic law, but if not proven as a hudd crime, it is dealt as a tazeeri crime under the Afghan Penal Code; it is essentially the crime of sexual intercourse outside of marriage].

Attempted zina is not a crime under the Penal Code nor is it a clear crime under Sharia law. UNAMA is of the view that regardless of arguments about the legality of "running away" itself, the use of running away to prove attempted zina as a crime is a misuse of the Penal Code and of Sharia law.

In August 2010, invoking Article 130 of the Constitution, the High Council of the Supreme Court, in approval number 572 "64, instructed prosecutors on how to handle 'run away' cases. According to the instruction, courts should assess whether the runaway is single or married, the cause and motive for running away, and the place to which the woman has run (a relative's or stranger's house). If a woman runs to escape harassment and disturbance by family members, and goes to a relative's house, to the house of a legitimate mahram (a close male blood relative or other legitimate chaperone) or to a justice institution, then this shall not be regarded as a crime from the Sharia perspective. Conversely, if the woman in question goes to a stranger's house, although the reason for running away may be to escape ill-treatment, the instruction states that she exposes herself to crimes such as "adultery and other associated offences" that, according to the High Council, are illegitimate under Sharia and thus prohibited and punishable.

The instruction was initially viewed as a way to stop the common practice of arresting girls who run away by qualifying that a woman who flees to a relative's house, justice institution, or other place cannot be arrested and limit police arrests.

\footnotetext{
${ }^{61}$ English translation of AGO instruction on non-prosecution of runaway cases that have not been criminalized under Afghan laws. 4 April 2012.

62 Information shared by International Development Law Organization ,Kabul, August 2012.

${ }^{63}$ Herat has the highest percentage of women incarcerated for runaway and moral crime cases. Of 137 women in female prison in Herat, 96 are convicted under article 427 of Afghan Penal code, chapter " Adultery, Pederasty and Violation of honor". UNAMA field monitoring, October 2012.

${ }^{64}$ Approval no. 572, a directive or instruction, was articulated in a letter, dated 1 August 2010, from the High Council of the Supreme Court, sent in response to a communication from the International Development Law Organization requesting clarification on the legal basis of arrest and prosecution for the crime of "running away." The response received was shared with UNAMA. The circular was also published in Islah Daily newspaper 25 August 2010.
} 
In practice, however the directive has been used to legitimize a traditional practice that restricts women's freedom of movement. It further allows arbitrary or selective applications of the law by the police and prosecution offices in a manner that also can violate fundamental rights and guarantees of women and girls protected under Afghan and international law, including the right to life, security of the person, freedom of movement, the right to health, and arbitrary or unlawful interference with privacy, family, or home.

In a meeting on 16 September 2012, Minister of Justice Habibullah Ghalib, Minister of Women's Affairs Ghazanfar, and Deputy Interior Minister Mirza Mohammad Yarmand all strongly condemned the wrongful imprisonment of women and girls on charges of 'running away. ${ }^{, 65}$ UNAMA is of the view that such official clarifications are very important and can contribute to protecting the many Afghan women and girls who are forced to flee their homes to escape violence. However such statements require adequate implementation by officials throughout the country and at all levels of the police and judiciary together with full continued high level political support.

Forced Self-immolation was reported as high among the grievous violence against women crimes. The ANP registered 34 cases, prosecutor's offices 34 cases, and city courts 17 such cases.

\section{Forced and underage marriages}

My uncle intends to marry me with his son for my property that I inherited from my late father, but I don't want a husband, rather I want to pursue my education and live with my mother.

9-year old girl/third-grade primary school student, in Baghlan province, April 2012. ${ }^{66}$

Forced and underage marriages, which represent one of the most deep-rooted and negative harmful practices, also remained a prevalent form of violence against women and girls as reported to UNAMA. Although this trend is not shown in statistics received from law enforcement authorities, several other sources, including DoWA and the AIHRC, reported these practices as the most widespread violations. Under-reporting of such violations was attributed to cultural and traditional factors, difficulties in reporting due to fear of reprisal, threat to life, and fear of being charged for "run-away" and adultery crimes.

\section{Ba'ad and exchange marriages}

UNAMA also documented nine cases of ba'ad or exchange marriages, in spite of the prohibition of these practices under article 25 of the EVAW law. It is noteworthy that in February 2012, the Attorney General's Office issued directives to prosecute perpetrators and facilitators of harmful practices, such as ba'ad, and forced marriages to enforce implementation of the EVAW. ${ }^{67}$ However, it is not clear what follow-up mechanism has been

\footnotetext{
${ }^{65}$ Special meeting held by the Parliamentary Commission on Women, Human Rights and Civil Society, Kabul, 16 September 2012.

${ }^{66}$ UNAMA interview with victim, Baghlan province,14 April 2012.

67 "Forced marriage and giving away as "ba'ad", which often cause domestic violence in future of family life like the recent worrying incidents of such happened in the country and covered broadly by media, are the most apparent instances of forbidden treatment in Sharia laws and statuary laws. Therefore, it is instructed that involved individuals (mediator, witness, attorney and issuer of marriage certificate) should be inquired
} 
put in place by the issuing authority to ensure that such instructions were disseminated and acted upon at the district levels and in remote areas by subordinate offices.

\section{Women Victim's Access to Justice}

I feel sorry for the violence against women victims who come to the hospital for treatment. Although they know they are victims of domestic violence, they simply say they fell down from stairs, they tripped, etc. possibly because they don't want to disclose identities of the perpetrators or do not want to spoil family relations.

-- Medical doctor, Takhar hospital. January $2012 .{ }^{68}$

UNAMA findings show that women and girl victims of violence continued to face challenges in accessing justice due to several factors. Many women victims of violence do not report their situation to law enforcement and judicial institutions due to cultural restraints, social norms and taboos, customary and religious beliefs relegating women to subordinate position, fear of social stigma, exclusion and, at times, even threat to life. As a result, many incidents of violence against women were not reported to formal law enforcement and justice institutions. For example, according to estimations of the AIHRC office in Paktya, almost 80 per cent of relevant cases were not reported to the ANP or the judiciary.

Other factors hindering victims and their families' access to justice included lack of trust in the ANP, prosecutors and DoWAs, absence of shelters, civil society organizations and women rights organizations and/or the AIHRC in certain areas, and lack of knowledge about the legal protection (the EVAW law) and mechanisms (DoWAs, shelters) of support for violence against women victims.

Women's shelters, a relatively new development in Afghanistan continued to play an often life-saving role by offering temporary safe refuge to women victims of violence. Afghanistan's Council of Ministers approved the country's first-ever Regulation on Women's Protection Centers on September 5, 2011. The regulation recognizes the critical service that shelters managed by either the Government or NGOs provide and sets standards for their operation designed to safeguard residents' rights and dignity. Although not a permanent solution for women victims of violence, the regulation's enforcement, along with creation of shelters in regions where they do not exist, may allow more women to obtain protections of the EVAW law and more generally from domestic violence.

These challenges in women's access to justice for violent crimes are further elaborated in the following sections along with illustrative cases.

\subsection{Dominance of Traditional Justice Mechanisms}

In a majority of rural areas, in particular in the south-east, south and eastern parts of the country traditional justice mechanisms (shuras and jirga) remain much more powerful than formally established courts, and serve as the cornerstone of dispute resolution and access to

and prosecuted in accordance with articles (25, 26, and 28) of EVAW laws." AGO Directive, 24 January 2012.

${ }^{68}$ UNAMA telephone interview with local doctor, Takhar 16 June 2012. 
justice for the vast majority of people69. In some remote Pashtun dominated areas, the society is governed by cultural norms that relegate women to a marginal role and do not consider them entitled to enjoy all their legal rights. UNAMA observed that the traditional moral code plays a predominant role in these areas, often overruling the principles of Sharia law. In these areas, the society and representatives of Afghan institutions appeared to be compelled to abide by these rules which, in some cases, were less protective of the rights of women than Sharia and Afghan laws. This situation contributed to a general lack of compliance with applicable laws by local institutions.

UNAMA monitoring found that in numerous instances of violence against women, ANP, prosecutors, DoWA and AIHRC also consulted traditional mechanisms. Decisions of these mechanisms were observed to often be shaped by powerful men in local areas applying a diverse range of procedures and based on a mix of tradition, Islamic law interpretations and local power relations. UNAMA observed that decisions were often not based on law or contrary to religious principles. As a result, vulnerable segments of society, especially women and children often faced further victimization. For example, a court may have sentenced a rapist to imprisonment and at the same time a community-based mechanism may have decided the rapist should marry the victim or called for a ba'ad exchange.

Predominant use of traditional justice mechanisms also resulted from closer accessibility to communities and the perception that they provide quick, cheap and culturally relevant and acceptable remedies.

\subsection{Increasing control of insurgents and insecurity in some areas}

If Afghan institutions cannot protect themselves, how can they protect me? ${ }^{70}$

Prevailing insecurity, lack of or poor Government control, weak rule of law and the absence of functioning courts, have further contributed to some communities' reliance on traditional justice mechanisms, which appeared to be increasingly governed by more conservative religious leaders with retrogressive attitudes towards women's position in society. UNAMA observed this trend in provinces and some districts where control by Anti-Government Elements was growing, such as in Nuristan, Paktika ${ }^{71}$, Paktiya ${ }^{72}$, Ghazni, Khost, Zabul, Urezgan, Kunar, Parwan (Siagird, Shinwary ${ }^{73}$ and Kohi Safi districts) Logar, Maidan Wardek,

\footnotetext{
${ }^{69}$ In Nangarhar province of 52 cases registered with DoWA, 17 were solved through Jirgas. Statistics gathered from the ANP, DoWA and AIHRC by UNAMA in August 2012.

70 UNAMA meetings with women in the eastern and southeastern regions. UNAMA field monitoring October 2011-September 2012.

71 In a meeting with UNAMA on 05 September 2012, the head of the Court of Appeal in Paktika province advised that the tashkil for the court and prosecutor's office was only 10 per cent complete because of weak Government influence and control, including in the capital Sharana. In another meeting with UNAMA on 6 September 2012, a member of the Provincial Council of Paktika province stated, "The formal justice system operates with its limited means and local authorities stated that the growing insurgency and low salaries were the two biggest obstacles confronting the justice sector in Paktika. The population remains intimidated by AGEs which directly impacts its willingness to use official channels of justice, which are often perceived as corrupted."

${ }^{72}$ According to the head of women's rights section of the AIHRC, Paktiya, at least 80 per cent of relevant cases were not reported to the ANP or the judiciary. Meeting with UNAMA, Paktiya -September 2012.

${ }^{73}$ On 8 July 2012, mobile phone footage of the public execution of a woman by Taliban on charges of adultery in Shinwary district of Parwan province was released by unknown sources.
} 
and Farah. ${ }^{74}$ In some districts in these provinces, Taliban parallel courts, jirgas, and traditional mechanisms were the only authorities providing governance and rule of law.

For example, in May 2012, in Paktiya province, the Taliban publically stoned a woman on charges of adultery. They were reportedly searching for the man involved who was also sentenced to the same punishment and had escaped. Government authorities in the province denied having any information on the incident. ${ }^{75}$

In other areas where women victims of violence sought to pursue justice through formal institutions, the growing number of activities by Anti-Government Elements hampered movement of civilians and exacerbated difficulties faced by women from districts and remote areas to access public offices. For example, UNAMA was informed that, after an incident in which the Head of DoWA was killed in Laghman, only two victims had visited the office in Mehterlam and submitted complaints since July $2012 .^{76}$ This suggests that women victims were concerned about being associated with the office and feared becoming a target.

Women victims told UNAMA "If Afghan institutions cannot protect themselves, how can they protect me?" Similarly, the current staff of the DoWA office in Lagman told UNAMA they continued to feel uncomfortable in carrying out their activities and that the office's ability to operate had been significantly hampered during the last four months. ${ }^{77}$

The fear of being arrested and facing further persecution by ANP for 'intention to commit zina' and for 'running-away' with a non-mahram, was another threat that women victims expressed concern with as a factor in their decision-making whether to leave their homes to make a complaint.

\subsection{Challenges with ANP, prosecution and courts}

As first points of contact, ANP and prosecutors play a key role in the protection of women victims of violence and in setting a course for proper application of the EVAW law. However, UNAMA monitoring indicates a loop of inefficiency, corruption and deficiencies at the investigation level by ANP and the prosecution that bars even some of the most serious cases from reaching the stage where the EVAW law could be implemented.

General challenges with the ANP and prosecution in denying women's access to justice were summed up by the AIHRC in Bamyan, at a press conference on 18 July 2012. ${ }^{78}$ UNAMA's observation confirmed the challenges expressed by AlHRC as a pattern in all provinces including: disregard of the principle of transparency in dealing with cases; prolonged delays in processing cases - frequently with disappearance of key documents and of evidence during the course of protracted proceedings; weak investigations; deficient and incompetent processes of collecting key witness statements to incorporate in dossiers; inconsistency in approaches towards suspects and accused in the same cases, in particular in cases involving influential/high profile people as accused persons, lack of accountability

\footnotetext{
74 In Farah province only 20 of 50 judicial posts are filled. Judicial officials operate from the provincial capital of Farah with no functioning courts in place. UNAMA field monitoring report for September 2012.

${ }^{75}$ Case reported to UNAMA, October 2012.

${ }_{76}$ UNAMA meeting with DoWA, September 2012, Laghman.

${ }^{78}$ Ibid.

78 AlHRC Bamyan Regional Office's press release, Dari: http://www.aihrc.org.af/fa/press-release/1105/pressrelease-bamian-office-.html , 18 July 2012.
} 
mechanisms within the police structure as well as the discriminatory attitudes of the police personnel towards women.

Other more specific concerns are outlined below.

\section{Mediation and withdrawal of complaints}

Consistent with UNAMA's previous findings, ANP and prosecutors often do not act as impartial enforcers of law and follow tradition, as opposed to the rule of law, in dealing with cases of violence against women. As noted above, in some instances, the ANP and prosecution refer cases to jirgas and shuras to seek their advice, which often leads to a reinforcement of harmful practices, including serious crimes, rather than following required legal procedures. ${ }^{79}$

In all provinces, initiation of mediation is always a first action point. Key institutional actors stated that mediation was an appropriate forum for couples to resolve their marital issues. Most cases reported to DoWA and to the ANP were dropped before they reached the prosecutor and the courts due to mediation leading to withdrawal of complaints, based on article 39 of the EVAW law. In Jawzjan, while the prosecution department claimed that it did not encourage victims to withdraw their complaints, the head of the appeal prosecution acknowledged that withdrawing a case at the prosecution level remained common. ${ }^{80}$

UNAMA found that the vast majority of violence against women cases referred to traditional mechanisms were solved without due oversight by the referring entity such as DoWA, ANP or prosecutors. Consequently, when a woman returned to her family following "successful" mediation, she remained at risk of recurrent violence. In instances where women's shelters were involved and where more active DoWA's operated, some safeguards were established through regular follow-up visits to monitor the well-being of a woman sent back to her house. However, UNAMA found that such practices were very rare and insufficient in ensuring full protection.

Sometimes mediation attempts by DoWA and ANP interfered and slowed the judicial process, resulting in women having to stay in shelters for lengthy periods. Although many women victims were separated from their children and led a restricted life, shelters were the

\footnotetext{
79 A case monitored by UNAMA of an 18 year-old girl from Nangarhar province who escaped a forced engagement and eloped with the man she wanted to marry was representative of this situation. The Afghan National Border Police (ANBP) arrested the couple before they reached Pakistan. The woman was sent to a shelter and the man to prison. The case was brought before a Jirga which decided that the family of the man who escaped with the victim had to give one girl each to the family of the woman and the family of the other man in ba'ad. Additionally, the family of the man had to pay Rs 600,000 (approximately USD 6, 000) to the family of the man chosen to marry her. The district ANP intervened since it considered the Jirga's decision illegal. However, instead of arresting all the alleged perpetrators, the ANP called for a new Jirga. The new decision was that the family of the woman had to give one girl in ba'ad to the family of the man chosen to marry her and Rs 300,000 (approximately USD 3,000) as compensation. The family of the woman expressed the wish to kill the daughter. However, the Jirga authorized her to marry the man she escaped with and obtained guarantees by her family they would not harm her. The ANP did not arrest anyone. In an interview with UNAMA HR the victim reported the following:

"When I was five, my family engaged me to a boy from the same village where I am from. However, I did not want to marry him... [eventually] there was a jirga with more than 100 elders from the village. They decided that the family of the man I was supposed to marry could take my nine-year-old sister in ba'ad. My family also had to pay some money. Now I am here at the women's center but soon I will go home to my family. After that, the man I love will formally ask my family to marry me and I will finally get married to him. In this way it is not shameful for my family".

${ }^{80}$ UNAMA meeting with Head of the Appeal Prosecution, Jawzjan, September 2012.
} 
only option of refuge for many as returning to their homes and communities would have serious implications for their security and, at times, for their life.

\section{Imbalance of power and alleged corruption leading to Impunity}

UNAMA observed patterns of reluctance to arrest perpetrators of violence against women connected to armed groups affiliated with Anti-Government Elements, or pro-Government militias, Arbaki, Afghan Local Police (ALP), influential persons from within or outside the Government, or those who could pay bribes. UNAMA observed that in some areas, ANP appeared powerless before perpetrators, while in other areas it appeared to side with perpetrators due to corruption and lack of impartiality in administering justice. This phenomenon, combined with lack of capacity, has contributed to widespread impunity for perpetrators of violence against women across the country.

The issue is illustrated by a case followed by UNAMA in Farah province. In April 2012, ANP in Farah received a complaint from the father of a woman who was locked up and mistreated by her husband. According to sources, she left home with the daughter of the man from his first marriage to escape the violent behavior of her in-laws. The ANP did not take action and advised the father to refer the case to the elders, as the incident occurred in a village controlled by insurgents. Reportedly, sometime later, the woman was killed along with daughter of the perpetrator who remained free. ${ }^{81}$

In another example documented by UNAMA, a 21-year old woman was shot and injured by her Arbaki husband in Balkh province, and the perpetrator was never arrested. Following mistreatment by her husband, the woman had fled her house and went to her parents' home. Her husband came to the house, shot her and her family (her father was killed and her mother was injured.) Reportedly, as a result of her injuries, the woman can no longer bear children and suffers from depression. The perpetrator fled and sources reported he may have been assisted by the ANP. ${ }^{82}$

UNAMA observed that inaction was quite frequent in instances where alleged perpetrators of violence against women were ANP members. ${ }^{83}$

Alleged corruption and incompetency also played a large role in shaping law enforcement. UNAMA documented many complaints of women and families who were poor and unable to pay bribes to officials resulting in their cases not being properly handled by justice actors. One example is a July 2012 case from Yakawlang district in Bamyan province, in which the prosecutor asked the family of an alleged rape victim to pay a bribe to investigate, prosecute and punish the perpetrators. The prosecutor was arrested in connection with this bribery incident in August 2012 by NDS and National Security Prosecution, but most other cases of bribery were not reported.

Similar findings were received from the Northern region. According to local sources, the handling of violence against women cases in Sari Pul and Jawzjan has been dysfunctional due to high levels of corruption. For example, a case in a remote village of Sari Pul city was reportedly handled by a corrupt prosecutor who received money from the woman's family

\footnotetext{
${ }^{81}$ Case monitored by UNAMA, April 2012, Farah province.

82 The case was reported in the Balkh Gender Based Violence Group's meeting held on 16 September 2012.

${ }^{83}$ UNAMA field monitoring, October 2011 to September 2012.
} 
and charged her for adultery as her family accused her of prostitution. The court however issued a more favorable decision for the woman (she was divorced and her husband was charged with one year' imprisonment) after DoWA's intervention ${ }^{84}$.

According to the Chief Prosecutor of Samangan, there is often interference of power brokers in the work of the prosecution department. However, he also said that the prosecution department is working on a reform plan to impose the recently released Presidential Decree \# 45 concerning anti-corruption. ${ }^{85}$

UNAMA also assessed that, in the majority of cases it monitored, the ANP did not properly investigate or arrest alleged perpetrators. Victims and other stakeholders interviewed reported that although they asked ANP repeatedly to investigate cases of violence against women, the ANP did not provide information on the type of investigations that were carried out to locate and arrest alleged perpetrators. Additionally, a number of cases were still reported by the ANP as under investigation although several months had passed without progress. Some victims and interlocutors reported to UNAMA that corruption among ANP officials was one of the main reasons for this lack of action. However, UNAMA was unable to corroborate these allegations in the absence of any evidence submitted.

\section{A. Lack of skills, capacity and competence}

UNAMA found that the process for women victims of violence to submit a complaint and have their rights protected was cumbersome. Often, victims were referred to offices that were not competent and did not have jurisdiction to decide on criminal cases of violence against women, such as the Family Court. For instance in Nangarhar, the AIHRC referred 45 victims of violence against women to the Family Court. Only 15 victims registered their cases as most of their cases were criminal, which the Family Court does not have jurisdiction to address. The Family Court referred the remaining cases to the prosecutor's office. ${ }^{86}$ However, UNAMA observed that women victims often expressed discouragement with the continuous referral from one office to another and abandoned their intention to pursue justice.

The appointment of prosecutors mandated to deal specifically with the EVAW law has been delayed, which has increased confusion and postponement in the referral of the cases. ${ }^{87}$

UNAMA findings also indicate that no standardized and systematic registration system of cases by the police, prosecutors and DoWA exists, and there is no adequate follow-up by these institutions after referral of cases to the next judicial authority. Precise statistics on the number of cases, types of crimes, and outcome of their respective activities was not available in almost all the provinces covered. These institutions have scattered data and mainly rely on the historical memory of the individual authority or official who worked on cases.

\footnotetext{
${ }^{84}$ Case shared by the head of DoWA in Sari Pul with UNAMA, 25 July 2012.

${ }^{85}$ UNAMA meeting with Samangan Chief Prosecutor, 12 September 2012.

${ }^{86}$ UNAMA HR meeting with the Head of the Family Court, September 2012.

87 According to information received from the International Development Law Organization (IDLO) the special Violence Against Women units attached with prosecutor's offices supported by IDLO in Kabul, Balkh, Herat, Badakhshan, and Nangarhar have been included in the Tashkil, and those for Kapisa, Parwan and Bamyan are under consideration. In addition, Violence against Women Commissions in Kandahar and Kunduz are in the Tashkil but are not supported by IDLO.UNAMA correspondence with IDLO, 12 November 2012.
} 
Moreover, civil cases pertaining to women, such as divorce and alimony, were also categorized as violence against women cases. In some provinces such as Bamyan, almost all cases involving women were registered by law enforcement authorities, DoWA and the AlHRC under the broad category of violence against women. Review of the specific circumstances of selected cases by UNAMA did not support their placement under this category. For example, in Bamyan cases of beating, in which victims included men and women as a result of an escalation of civil/ land disputes were put under violence against women.

UNAMA notes however that the EVAW law itself does not account for specific circumstances and intent as a requirement for the crime, which could arguably be a limitation in the law. For example, several categories of serious violations listed as violence against women by the AIHRC and DoWA do not amount to crimes under the EVAW law - such as honour killing, and wrongful victimization of women and girls running away from home to escape violence or forced marriages. This situation also complicates the development and use of a commonly understood and shared system of registration and classification of violence against women incidents and crimes under the EVAW law.

The issue of the capacity of the police also remains to be addressed. The lack of empowered female police staff appointed as investigation officers has been highlighted in many reviews and reports. The Family Response Units are being strengthened and expanded across the country with the support of the international partners. However, their coverage of remote areas remains limited and their actual capacity to deal with all types of violence against women cases, including grave crimes, has yet to be established.

The role of female police in addressing violence against women complaints cannot be overstated in the context of Afghanistan where women prefer to talk to women on matters pertaining to their personal lives. The Ministry of Interior's strategy calls for a corps of 5,000 women police officers by 2014 , but there remain a number of challenges to reaching this goal. Obstacles to recruiting and retaining women police, include: traditions and customs that do not support entry of women in the police force; low literacy; lack of security, lack of childcare, threats and fear of retaliation by anti-Government elements, and more importantly allegations of widespread sexual harassment of women within the police. ${ }^{88}$

Generally a lack of required skills in conducting investigations has also hampered professional handling of violence against women cases. This was observed more clearly in cases of forced self-immolation which, due to lack of proper forensic, crime scene and circumstantial evidence investigations, were often treated as regular 'suicide' incidents. ${ }^{89}$

\footnotetext{
${ }^{88}$ See A Long Way to Go; Implementation of the Elimination of Violence against Women law in Afghanistan http://unama.unmissions.org/Portals/UNAMA/human\%20rights/November\%2023 UNAMA-OHCHR-Joint-Reporton Implementation-of-EVAW-law ENG.pdf.

${ }^{89}$ UNAMA field monitoring, October 2011 to September 2012
} 


\section{B. Discriminatory attitudes and low priority}

The prosecutor has lost the case file of $x x x$, who was assaulted. The prosecutor has exonerated the perpetrator. It shows indifference in record keeping and prosecution of violence against women cases."

-- ANP official, district Cha Ab, Takhar province, August 2012. ${ }^{90}$

UNAMA found that law enforcement authorities sometimes do not take violence against women cases seriously and act on them very slowly. Officials were reported to have stated that such cases were "family matters" and must be dealt with at the family and community level. Prosecuting and judging perpetrators of violence against women cases often was not a priority for judicial authorities. For example, in Balkh, authorities reported they were often unable to accept new detainees due to overcrowded prisons. Thus, in some cases, the Violence against Women Unit of the Prosecution Department decided not to detain perpetrators of violence against women..$^{91}$ UNAMA was also frequently told that putting the accused man behind bars would leave their family suffering economically, as men were the bread-winners.

In Maimana, a prosecutor interviewed by UNAMA stated that empowering women leads to more divorces. He related the case of his driver's wife who decided to leave her husband because of a small dispute which did not turn violent. He stated that women also tended to misuse the law to their advantage, and complained that the law does not provide protection for men who were mistreated by women. ${ }^{92}$

\section{Poor knowledge of Violence against Women and the EVAW Law}

UNAMA observed that lack of a clear understanding of the roles and responsibilities of DoWAs, ANP, prosecution and judges dealing with cases of violence against women, and lack of proper knowledge of the EVAW law, all hindered women's access to justice.

UNAMA observed that officials who were not aware of the EVAW law provisions, did not consider certain acts which amounted to violence against women under the EVAW law as crimes and, as a result, perpetrators of such acts were not prosecuted. UNAMA assessed that certain types of crimes, including beatings, domestic violence, forced and exchanged marriages, ba'ad, and child marriages were not viewed by authorities as grave crimes and were therefore not submitted for prosecution as required under the EVAW law. Limited knowledge of the applicable legal framework jeopardized their ability to investigate and prosecute a crime under the applicable law resulting in violence against women cases addressed under the more familiar Penal Code.

In Faryab, sources told UNAMA that suspects in violence against women cases at the district level were often offering money to prosecutors to be charged under the Penal Code rather than the EVAW law to benefit from a presidential pardon ${ }^{93}$.

\footnotetext{
${ }^{90}$ UNAMA telephone interview with a CID official of District ChahAb, Takhar, 5 August 2012.

91 UNAMA interview with the Head of Special Unit on Violence against Women of Prosecution Department, Balkh, 21 October 2012.

92 UNAMA interview with prosecutor, Maimana, 8 August 2012.

93 UNAMA interview with staff member of investigation unit of Faryab Prosecution Department, Maimana, June 2012.
} 
Based on interviews with prosecutors and judges, UNAMA observed this occurs for two reasons: lack of ratification of the EVAW law by the Parliament and the fact that some crimes in the EVAW law are also included in the Penal Code. Therefore, judges and prosecutors continue to refer to the lex generalis rather than to the lex specialis. Coexistence of similar provisions in the EVAW law and the Penal Code has generated confusion and may lead to a not fully accurate analysis and protection of women's rights in the judicial system. The low number of cases decided under the EVAW law does not necessarily mean women's rights were not protected in a particular case since cases may have been decided under the Penal Code. As noted earlier in this report, consideration should be given to harmonizing and clarifying the application of the EVAW law and Penal Code in violence against women cases in the aim of maximizing protection of women and their rights to be free from violence and secure justice.

\section{Commissions on Elimination of Violence against Women}

Most of the EVAW commission members, being present symbolically at the meetings and certainly do not believe on women rights. They just come together to show themselves in the eyes of one another to pass the time. Therefore political will is a must for reducing violence against women and at the provincial level this is the responsibility of Provincial Governor to make all his line departments accountable.

-- A DoWA official, Baghlan. ${ }^{94}$

The High Commission on Elimination of Violence against Women, regularized under the EVAW law in August 2009, and established in 2009 has served as a comprehensive mechanism for the promotion of all aspects of the EVAW law. The High Commission is chaired by the Minister of Women's Affairs and has actively engaged in key issues under its mandate. Recently it also finalized its terms of reference and those of its provincial subordinate arms.

The provincial Commissions, on the other hand, present a diverse picture. Commissions have been established in 28 of Afghanistan's 34 provinces. ${ }^{95}$ UNAMA's recent monitoring indicates that in most of these provinces the commissions are either not active or not effectively functioning. No uniformity exists regarding the role of chair as, in many provinces, DoWA remained the chair despite instructions issued in late 2010 by Secretariat of the High Commission on Elimination of Violence against Women assigning provincial Governors to serve as chairs. The provincial commissions' role in the prevention of and response to violence against women has largely remained contingent upon active support, patronization and individual interest from the respective chairs. For instance in Bamyan province, the commission is chaired by the Governor and has so far proved to be an effective vehicle in responding to violence against women cases and in advocating for due process of justice. However, UNAMA observed that the commission made more recommendations and actively followed up on action points when the Governor attended meetings.

\footnotetext{
${ }_{94}^{9}$ UNAMA interview with aDoWA official, Baghlan, 16 September 2012.

${ }^{95}$ The six provinces where commissions have not been established are Helmand, Kabul, Kandahar, Nuristan, Paktika and Zabul.
} 
Other provincial Commissions chaired by Governors, such as in Maidan Wardek, Ghazni, Faryab, Kunduz and Sari Pul, did not convene regularly and have not been effective. In other areas, for example in Khost, Ghazni and Paktya, provincial commissions have resorted to less controversial aspects of women's issues by engaging more in raising awareness on women's rights within Islam. In many provinces, the commissions still did not have proper terms of reference or a work plan and did not hold regular meetings. Where meetings were held, they focused on up-dates from individual members of their activities and did not address the structural or policy issues required for effective prevention and response to violence against women, nor did they have a mechanism to follow up incidents of violence against women brought to their attention.

UNAMA noted that provincial commissions require more support and better oversight mechanisms from the High Commission in Kabul to enable them to be more effective in implementing their challenging mandate. ${ }^{96}$

\subsection{Departments of Women Affairs}

UNAMA's meetings with various heads of Departments of Women Affairs (DoWA) indicated their continuous struggle and challenges in providing protection and services to victims of violence against women. In many provinces in the Central Highlands, north, north-east, south-east, and western regions, DoWAs effectively engaged in raising awareness on women's rights issues and on the elimination of violence against women and the EVAW law. In some of those provinces, interlocutors interviewed stated that awareness-raising efforts contributed to increased reporting of violence against women incidents.

Where UNAMA observed some very positive examples of DoWA's role in addressing violence against women incidents, it also noted that the effectiveness of the DoWA largely depended on the personal commitment of those heading the various offices. In many areas, DoWAs have provided an effective mechanism for reporting violence against women incidents, where victims feel more comfortable and secure to share their plight. In some instances, DoWAs have also been effective in preventing certain violations. For example in Baghlan province, a nine-year old girl approached DoWA to report that her uncle was planning to marry her with his son as a way to appropriate her inherited land. ${ }^{97}$ DoWA assisted her in civil proceedings in the provincial Court, which granted her the inheritance and appointed her mother as her guardian. The Court also ordered her uncle to abandon his plans of forced and child marriage.

In other instances, DoWA heads have been the subject of corruption allegations and accused of putting women victims of violence at further risk. An incident of alleged corruption

\footnotetext{
${ }^{96}$ Article 16 of the EVAW law describes the Commission's duties as including researching the causes of violence and undertaking preventive measures; designing anti-violence publicity and public awareness programs; coordinating Government and non-government activities to combat violence; collecting statistics and information on cases of violence, including from the police, prosecutor and courts; and proposing regulations and adopting procedures for better implementation of the EVAW law.

97 "My, uncle intends to marry me with his son for my property that I inherited from my late father, but I don't want a husband, rather I want to pursue my education and live with my mother."

-- RA, 9-year old girl and student of grade three from Khenjan District, Baghlan province, interviewed by UNAMA on 14 April 2012 in Pulikhumri.
} 
of a head of DoWA that led to a victim's killing shows the need for proper vetting of candidates for such responsible and sensitive positions. ${ }^{98}$

Proper record-keeping and registration of violence against women by DoWA offices cases remains a challenge. For instance in Baghlan, the DoWA office did not have an organized record of violence against women cases that it had been reporting to UNAMA. DoWAs also continued to use mediation or referral to TDR mechanisms, including for serious crimes. The DoWA office in Nimroz informed UNAMA that all cases it had received in the past year, including murder, rape, forced self-immolation and adultery, were either mediated or referred to local elders which is inconsistent with requirements under the EVAW law.

\section{Conclusion}

UNAMA welcomes the Government's commitment to eliminating violence against women and improving implementation of the EVAW law. At the same time, serious concerns remain in laws, policies and practice to prevent and address violence against women.

Since the entry into force of the EVAW law, the Attorney General's Office has issued three directives/instructions on proper implementation of the law, prosecution of perpetrators involved in harmful traditional practices of forced marriages and ba'ad, and on wrongful prosecution of women running away from homes on charges of zina or intent to commit zina. $^{99}$ The effective implementation and enforcement of these instructions by prosecutors across the country remains sporadic. UNAMA findings suggest that, although prosecution offices are increasingly applying the EVAW law in indictments and convictions of violence against women cases, these are still a small percentage of the overall number of violence against women incidents received by law enforcement authorities and DoWAs. The application of the EVAW law is even lower at the level of courts.

UNAMA's findings also suggest that awareness-raising initiatives by women's rights and civil society organizations as well as DoWAs in some provinces have contributed to increased reporting of violence against women incidents to law enforcement authorities, DoWAs and AlHRC. In spite of these efforts, victims' access to justice largely remains limited and is hampered by a number of factors discussed in this report. Most of the challenges women faced in accessing justice occurred in the investigation and prosecution stages; a fact that often renders the question of implementation of the EVAW law by the courts a moot point. More efforts are needed to improve reporting, registration and investigation of violence

\footnotetext{
${ }^{98}$ On 18 February 2012, a 20-year old woman,, from Ahmad Abad district in Paktya province, was allegedly shot and killed by her husband. Reportedly, the victim had earlier escaped domestic violence and was raped by her father-in-law and sought assistance from the head of DoWA in Paktiya, who kept her at her house for six days and allegedly called the family of the victim informing them that their daughter was kidnapped by insurgents who demanded 300,000 Pakistani Rupees for her return. It was alleged that in a meeting arranged at the DoWA compound, the head of DoWA handed the victim back to her family after receiving the "ransom money". A few days later the victim was shot and killed by her husband. Investigation by the ANP CID and police in Paktya revealed that the head of DoWA was not involved in the victim's killing. Police arrested the husband and fatherin-law and the case was transferred to the primary court. The Deputy Governor of Paktiya confirmed the removal of the head of DoWA by MoWA through a letter to the Afghan Independent Civil Service Commission. On 14 September, a new acting head of DoWA took over responsibilities of the department. UNAMA monitoring and meetings with the CID, AIHRC, and a member of the Women's Shura and Provincial Council.

99 (i)- AGO Directive on Implementation of EVWA Law- 18-10-89 issue No: 35/155 - (ii)-AGO Directive on Prosecution of individuals (mediator, witness, attorney and issuer of marriage certificate) involved in forced marriages and Ba'ads - 24/01/2012 - (iii)- AGO instruction on non-prosecution of runaway cases that have not been criminalized under Afghan Laws, 4 April 2012.
} 
against women cases at the police and prosecution level to improve implementation of the EVAW law.

Systematic and standardized registration of violence against women cases by the DoWAs, police, prosecution offices and primary courts is imperative in understanding the scope, nature and severity of the causes of violence against women, which can better inform remedies and solutions. Further, building the capacities of law enforcement personnel, training and awareness-raising to enable civil society organisations to monitor implementation, and education for the general public about the EVAW law, should remain a continued focus at all levels.

UNAMA expects that, in view of renewed commitments under the Tokyo Mutual Accountability Framework, the Government, with support from international partners, will make greater efforts to ensure respect for women's rights and improved protection for victims of violence against women through the EVAW law. UNAMA offers the following recommendations to support strengthened implementation of the EVAW law and improved protection of women from violence.

\section{Recommendations}

\section{To the Government of Afghanistan}

- At the highest levels, including the President, continue to publicly emphasize that promotion and protection of women's rights is an integral part and main priority of peace and reconciliation throughout Afghanistan, and a central pillar of the country's political, economic, and security strategies.

- The President's office to issue instructions to Provincial Governors reminding them of their responsibility to take leadership of provincial Commissions for the Prevention of Violence against Women further to directions from the High Council for Prevention of Violence against Women.

- In conjunction with the international community develop a monitoring framework of the commitments in the Tokyo Declaration and the Presidential Decree 45 specific to gender equality, women empowerment, and effective implementation of the EVAW law.

To the Ministry of Women's Affairs and the High Commission for the Prevention of Violence against Women

- Establish an oversight mechanism to monitor performance of the provincial Commissions and assist them in the development of work plans and acquiring knowledge and skills needed to fulfill their responsibilities.

- Invite civil society, including representatives of women's rights NGOs, shelter managers and international partners, to attend High Commission meetings as observers, to report on specific issues, and to actively support the Commission's work. 
- Design and implement referral mechanisms at the district level, coordinated by the representative office of one of its members, to facilitate and follow up referral of victims of violence against women to appropriate law enforcement institutions or service providers on shelter, psycho-social support, legal aid, health care, pursuant to article 16 of the EVAW law.

- Develop a guideline on the application of mediation that could be used by the department of women's affairs, police and prosecutor's offices including special violence against women units to fully protect victims of violence.

- Ministry of Women's Affairs coordinate with the Mol, MoJ, and AGO to develop a standard classification and categorization criteria to be commonly used by all law enforcement institutions and departments of women's affairs for registration of all forms of violence against women cases, including those not criminalized under the EVAW law such as honour killings and so-called "moral crimes", separate from civil cases relating to women.

\section{To the Ministry of Justice}

- With the High Commission on the Prevention of Violence against Women and the National Legal Training Centre, provide training for judicial officials on the EVAW law. Consider involving judges and prosecutors who are successfully applying the law to train other judicial officials.

- Ensure that any law defining the relationship between the formal justice system and traditional mechanisms for dispute resolution (jirgas and shuras) improves their compliance with all national laws, including the EVAW law, and prohibits them from resolving serious crimes.

\section{To the Supreme Court}

- Issue clarifications and instructions to the courts on the provisions of the EVAW law, including their mandatory application in conjunction with other Afghan laws.

- Ensure all judges are trained on the EVAW law as part of mandatory training for judges.

- Instruct the General Criminal Division and the Inspection Department to particularly monitor the courts' proper application of the EVAW law to cases of violence against women.

- Consider establishing divisions within Family and City Courts throughout the country devoted to crimes of violence against women. Judges in these courts would develop expertise and help relieve the overcrowded dockets of the General Penal division.100

\footnotetext{
100 See article 61 (2) of the Law on the Structure and Jurisdiction of Judiciary of the Islamic Republic of Afghanistan. "If required, the Supreme Court may, after the approval by the President, establish other tribunals within the provincial center primary court. If needed, the head of provincial center primary court may temporarily assign a member of one tribunal to another."
} 
- Issue a clear interpretation of Article 398 of the Penal Code that mitigates punishment for killings perpetrated in the name of "honour" to avoid its misuse, and work toward its repeal.

\section{To the Office of the Attorney General}

- Consider tasking the Special Violence against Women Unit in Kabul with responsibility to monitor and follow up on all cases of violence against women that reach the Supreme Court. This could be specified in the Tashkil for 2013.

- Ensure that the General Penal Department (Saranwali Jazai Omomi) and other appropriate divisions of the AGO monitor how prosecution offices are applying the EVAW law.

- Continue to create and support commissions or units in provincial prosecution offices dedicated to prosecuting cases of violence against women with qualified staff and adequate resources.

- Develop a central database of all violence against women cases for all prosecution offices and special units on violence against women attached to prosecution offices Encourage proper investigation and prosecution of violence against women cases through performance appraisals of the frontline prosecution officers by adding a performance indicator on handling such cases.

\section{To the Ministry of Interior}

- Include sensitization on violence against women as part of basic police training and the police's role in responding to the victims needs in accordance with the EVAW law.

- Provide guidelines for the police Criminal Investigation Division (CID), including the Family Response Unit (FRU), clarifying the type of offences that must be investigated and forwarded to the prosecution and those that may be mediated by police, and ensuring that all cases mediated or referred for mediation by Police are properly registered and officially documented.

- Provide special training on the EVAW law for all police working with the FRU.

- Ensure that women approaching police stations can consult immediately with the FRU.

- Ensure that the FRU remains part of CID, that its officers benefit from training on investigative techniques and are able to fully participate in investigations of crimes involving domestic violence, rape or other types of violence against women.

- Ensure that female police officers are assigned to professional duties and given equal consideration for promotions.

- Create an effective mechanism for proper registration and follow-up of violence against women cases that are mediated to ensure protection of victims once they return to their families/communities. 
- Develop a central database of all violence against women cases with inputs from the CID, Family Response Units and other police departments concerned.

- Encourage proper registration, investigation and prosecution of violence against women cases through performance appraisals of the frontline police officers by adding a performance indicator on handling of violence against women cases.

\section{To International Donors}

- Support the Government in the implementation of the Tokyo Declaration through channelling development assistance towards commitments made under the Tokyo Declaration on gender equality, women's empowerment and the EVAW law implementation and develop a joint monitoring framework with specific indicators to measure progress in these areas.

- Support the Government in implementing the 2008-18 National Action Plan for the Women of Afghanistan (NAPWA); in particular in developing and putting in place a national strategy to implement the EVAW law, and by providing support for the National Priority Programs "Law and Justice for All" and "Capacity Development to Accelerate NAPWA Implementation".

- Expand programs that provide technical assistance and support for provincial prosecution offices and courts, particularly aimed at implementation of the EVAW law.

- Increase support for women's protection centers/shelters that offer refuge and support to female victims of violence. 